\title{
Chloride - The Underrated Ion in Nociceptors
}

\author{
Bettina U. Wilke, Kai K. Kummer, Michael G. Leitner and Michaela Kress* \\ Institute of Physiology, Department of Physiology and Medical Physics, Medical University of Innsbruck, Innsbruck, Austria
}

In contrast to pain processing neurons in the spinal cord, where the importance of chloride conductances is already well established, chloride homeostasis in primary afferent neurons has received less attention. Sensory neurons maintain high intracellular chloride concentrations through balanced activity of $\mathrm{Na}^{+}-\mathrm{K}^{+}-2 \mathrm{Cl}^{-}$cotransporter 1 (NKCC1) and $\mathrm{K}^{+}-\mathrm{Cl}^{-}$cotransporter 2 (KCC2). Whereas in other cell types activation of chloride conductances causes hyperpolarization, activation of the same conductances in primary afferent neurons may lead to inhibitory or excitatory depolarization depending on the actual chloride reversal potential and the total amount of chloride efflux during channel or transporter activation. Dorsal root ganglion (DRG) neurons express a multitude of chloride channel types belonging to different channel families, such as ligand-gated, ionotropic $\gamma$-aminobutyric acid (GABA) or glycine receptors, $\mathrm{Ca}^{2+}$-activated chloride channels of the anoctamin/TMEM16, bestrophin or tweety-

OPEN ACCESS

Edited by:

Jing Hu,

Heidelberg University, Germany

Reviewed by:

Miklós Antal,

University of Debrecen, Hungary

Rita Bardoni,

University of Modena and Reggio

Emilia, Italy

*Correspondence:

Michaela Kress

michaela.kress@i-med.ac.at

Specialty section:

This article was submitted to

Perception Science,

a section of the journal

Frontiers in Neuroscience

Received: 14 December 2019

Accepted: 12 March 2020

Published: 08 April 2020

Citation:

Wilke BU, Kummer KK,

Leitner MG and Kress M (2020)

Chloride - The Underrated lon

in Nociceptors.

Front. Neurosci. 14:287.

doi: 10.3389/fnins.2020.00287 homolog family, CLC chloride channels and transporters, cystic fibrosis transmembrane conductance regulator (CFTR) as well as volume-regulated anion channels (VRACs). Specific chloride conductances are involved in signal transduction and amplification at the peripheral nerve terminal, contribute to excitability and action potential generation of sensory neurons, or crucially shape synaptic transmission in the spinal dorsal horn. In addition, chloride channels can be modified by a plethora of inflammatory mediators affecting them directly, via protein-protein interaction, or through signaling cascades. Since chloride channels as well as mediators that modulate chloride fluxes are regulated in pain disorders and contribute to nociceptor excitation and sensitization it is timely and important to emphasize their critical role in nociceptive primary afferents in this review.

Keywords: anoctamin 1, glycine receptor, GABA receptor, NKCC1, KCC2

\section{INTRODUCTION}

In the past, excitation of primary afferent neurons has been associated mainly with cation fluxes across the cell membrane, setting the neurons' excitability, responsiveness to tissue damaging stimuli as well as action potential (AP) generation and propagation. However, the dynamic of $\mathrm{Cl}^{-}$homeostasis and the role of $\mathrm{Cl}^{-}$fluxes across the cell membrane in primary

Abbreviations: 5-HT, serotonin; Ano, anoctamin; AP, action potential; Best, bestrophin; CCC, cation-chloride cotransporter; CF, cystic fibrosis; CFTR, cystic fibrosis transmembrane conductance regulator; ClCA, chloride channel accessory; $\mathrm{IP}_{3}$, Inositol-1,4,5-trisphosphate; $\mathrm{SDH}$, dorsal horn of the spinal cord; GABA, $\gamma$-aminobutyric acid; GlyR, glycine receptor; GPCR, G-protein coupled receptor; KCC, $\mathrm{K}^{+}-\mathrm{Cl}^{-}$Cotransporter; MAC, maxi-anion channel; NKCC, $\mathrm{Na}^{+}-\mathrm{K}^{+}-2 \mathrm{Cl}^{-}$cotransporter; $\mathrm{PGE}_{2}$, prostaglandin E2; PIP 2 , phosphatidylinositol-4,5-bisphosphate; S1P, sphingosine-1phosphate; VGCC, voltage-gated calcium channels; VRAC, volume-regulated anion channel; VSOAC, volume-sensitive organic osmolyte anion channel. 
afferents and their spinal connections are gaining increasing attention and turn out to be of critical importance in particular for the development and maintenance of neuropathic pain. In the following review we will summarize which chloride conductances are expressed in DRG neurons and what is currently known about their contribution to nociception and chronic pain development.

\section{$\mathrm{Cl}^{-}$ION HOMEOSTASIS IN DRG NEURONS}

The intracellular $\mathrm{Cl}^{-}$concentration of neurons is maintained by cell membrane transporters including $\mathrm{Na}^{+}-\mathrm{K}^{+}-2 \mathrm{Cl}^{-}$ cotransporter 1 (NKCC1), or $\mathrm{K}^{+}-\mathrm{Cl}^{-}$cotransporter 2 (KCC2), the latter becomes prominent in mature neurons (Payne et al., 2003; Ben-Ari et al., 2012; Kaila et al., 2014). Both transporters mediate electroneutral transport of $\mathrm{Cl}^{-}$and utilize the electrochemical gradient generated by the $\mathrm{Na}^{+}-\mathrm{K}^{+}$ATPase . KCCs in general extrude $\mathrm{Cl}^{-}$from the cell leading to low intracellular $\mathrm{Cl}^{-}$concentration and a negative equilibrium potential for $\mathrm{Cl}^{-}$, while NKCCs increase cytoplasmic $\mathrm{Cl}^{-}$ concentration by shuffling $\mathrm{Cl}^{-}$into the cell resulting in a more depolarized $\mathrm{Cl}^{-}$equilibrium potential. When the intracellular $\mathrm{Cl}^{-}$concentration is very low and the $\mathrm{Cl}^{-}$equilibrium potential $\left(\mathrm{E}_{\mathrm{Cl}-}\right)$ is below the resting membrane potential $\left(\mathrm{V}_{M}\right)$ of the respective neuron, $\mathrm{Cl}^{-}$influx leads to hyperpolarization mediated by net inward flux of negative charge. In contrast, at high intracellular $\mathrm{Cl}^{-}$concentration, activation of a $\mathrm{Cl}^{-}$ conductance will depolarize the cell due to $\mathrm{Cl}^{-}$efflux. However, this may still cause inhibition of the respective neuron via two mechanisms: (1) slow membrane depolarization by $\mathrm{Cl}^{-}$efflux causes inactivation of voltage-gated $\mathrm{Na}^{+}$channels that results in reduced excitability and (2) increased $\mathrm{Cl}^{-}$conductance reduces the input resistance of the membrane 'shunting' electrical input upon stronger depolarization (Price et al., 2009; Kaila et al., 2014). Strong and rapid depolarization occurs if $\mathrm{E}_{\mathrm{Cl}}$ is near the AP threshold resulting in AP discharge (Prescott et al., 2006; Price et al., 2009).

In contrast to other cell types, sensory neurons, whose cell bodies reside in the DRG, express sustained NKCC1, KCC1 and KCC3 activity but low or even undetectable KCC2 (Rivera et al., 1999; Sung et al., 2000; Kanaka et al., 2001; Coull et al., 2003; Gilbert et al., 2007; Price et al., 2009; Pieraut et al., 2011; Lucas et al., 2012). Because KCC1 and -3 activity is increased by cell swelling but is low under isoosmotic conditions, these cationchloride cotransporters (CCCs) do not significantly reduce the intracellular $\mathrm{Cl}^{-}$concentration (Gamba, 2005). This is supported by the finding that KCC3 ablation in nociceptors does not affect heat sensitivity (Ding and Delpire, 2014). Therefore, mainly NKCC1 determines the high intracellular $\mathrm{Cl}^{-}$levels in mature DRG neurons in normal isotonic situation. In addition to CCCs, also the $\mathrm{Na}^{+}$-independent $\mathrm{Cl}^{-}-\mathrm{HCO}_{3}{ }^{-}$-anion exchanger $\mathrm{AE} 3$ might contribute to the intracellular $\mathrm{Cl}^{-}$accumulation (Pfeffer et al., 2009). This transporter is expressed in $\sim 60 \%$ of peptidergic and $\sim 30 \%$ of non-peptidergic DRG neurons (Barragan-Iglesias et al., 2014). The actual reversal potential for $\mathrm{Cl}^{-}$in DRG neurons is subject to regulation and varies between $-20 \mathrm{mV}$ and $-70 \mathrm{mV}$ (Gilbert et al., 2007; Funk et al., 2008). Therefore, activation of $\mathrm{Cl}^{-}$channels usually will cause depolarization, and the degree and velocity of depolarization determines whether this has inhibitory or excitatory consequences (Sung et al., 2000; Prescott et al., 2006; Gilbert et al., 2007; Funk et al., 2008). Furthermore, localized signaling and intracellular $\mathrm{Cl}^{-}$diffusion additionally increase heterogeneity and complexity of anion currents (Kuner and Augustine, 2000; Gulledge and Stuart, 2003; Doyon et al., 2011; Raimondo et al., 2012). Thus, depending on spatial and temporal fluctuations of $\mathrm{Cl}^{-}$levels, $\mathrm{Cl}^{-}$ion channel activation can have different effects on the overall activity of primary afferents.

CCCs, like NKCC, KCC and the $\mathrm{Na}^{+}-\mathrm{Cl}^{-}$-cotransporter NCC, and anion transporters such as the $\mathrm{Na}^{+}$-dependent $\mathrm{Cl}^{-}$$2 \mathrm{HCO}_{3}{ }^{-}$-exchanger and the $\mathrm{Na}^{+}$-independent $\mathrm{Cl}^{-}-\mathrm{HCO}_{3}{ }^{-}$anion exchanger, link different ion species including $\mathrm{H}^{+}$and $\mathrm{HCO}_{3}{ }^{-}$and even the membrane potential to $\mathrm{Cl}^{-}$level regulation (Doyon et al., 2011, 2016). In addition, $\mathrm{Cl}^{-}$channels are permeable to other anions, of which $\mathrm{HCO}_{3}{ }^{-}$is physiologically most important since sustained $\mathrm{HCO}_{3}{ }^{-}$outward flux through anion channels is ensured by free diffusion of $\mathrm{CO}_{2}$ across the membrane (Price et al., 2009). This allows for constant replenishment of $\mathrm{HCO}_{3}{ }^{-}$catalyzed by carbonic anhydrase which is detectable in $\sim 30 \%$ of DRG neurons (Prabhakar and Lawson, 1995; Price et al., 2009). The contribution of $\mathrm{HCO}_{3}{ }^{-}$to the total anion current through the open anion channels can change when the driving force for $\mathrm{Cl}^{-}$is altered due to a reduction in $\mathrm{Cl}^{-}$gradient (Cordero-Erausquin et al., 2005). A collapse of the $\mathrm{Cl}^{-}$gradient can lead to an increased proportion of $\mathrm{HCO}_{3}{ }^{-}$ to the total anion current or even to a biphasic anion current response. The $\mathrm{E}_{\mathrm{Cl}-\mathrm{can}}$ change rapidly, particularly during strong activation and in small compartments, or on a long time range during pain conditions due to regulation of CCCs (Coull et al., 2003; Funk et al., 2008; Wright et al., 2011; Doyon et al., 2016; Li et al., 2016).

As a consequence of the high intracellular $\mathrm{Cl}^{-}$concentration mediated by the active accumulation of $\mathrm{Cl}^{-}$by NKCC1, for example GABA-evoked depolarizing currents are observed in primary afferents at resting membrane potential (Sung et al., 2000); likewise, activation of $G$ protein-coupled receptors, e.g. by lysophosphatidic acid (LPA) and sphingosine-1phosphate (S1P), has been shown to activate excitatory chloride conductances (Ponsioen et al., 2009; Camprubi-Robles et al., 2013; Qi et al., 2018).

In contrast to the well-established contribution of deregulated CCCs with disturbed $\mathrm{Cl}^{-}$homeostasis and rising $\mathrm{Cl}^{-}$levels in spinal cord neurons to the pathophysiology of pain disorders (Coull et al., 2003), the regulation of CCCs in primary sensory neurons in inflammation and pain is still controversially discussed. In an arthritis model, NKCC1 is downregulated, whereas sciatic nerve injury and inflammatory mediators increase NKCC1 expression and activity (Morales-Aza et al., 2004; Funk et al., 2008; Chen et al., 2014; Modol et al., 2014). At the same time, these mediators reduce expression of KCC2 in DRGs, which leads together with NKCC1 activation to increased intracellular $\mathrm{Cl}^{-}$levels and nociceptor excitability (Funk et al., 2008; Pieraut et al., 2011). Thus, persistent inflammation 
can increase GABA-induced depolarization by affecting $\mathrm{Cl}^{-}$ homeostasis in DRG neurons (Zhu et al., 2012), while ablation of NKCC1 or pharmacological inhibition by bumetanide increases the latency in the hot plate or tail flick tests and alleviates thermal and mechanical hypersensitivity after sciatic nerve lesion (Modol et al., 2014). Similarly, the $\mathrm{Cl}^{-}-\mathrm{HCO}_{3}^{-}$exchanger AE3 is upregulated in a formalin-induced pain model and a $\mathrm{Cl}^{-}-\mathrm{HCO}_{3}{ }^{-}$anion exchange inhibitor blocks the evoked allodynia and hyperalgesia (Barragan-Iglesias et al., 2014). These reports highlight the significance of $\mathrm{Cl}^{-}$homeostasis and $\mathrm{Cl}^{-}$ conductances in nociceptors.

\section{CHLORIDE CHANNELS/TRANSPORTERS EXPRESSED IN PRIMARY SENSORY AFFERENTS}

$\mathrm{Cl}^{-}$conductances in primary afferents can be carried by different members of the chloride channel superfamily (Figure 1) and are of importance at the peripheral nerve terminal in the target tissue, along the peripheral axon, on the cell soma, as well as at synaptic terminals within the spinal dorsal horn. However, neuromorphological evidence regarding the subcellular localization of the chloride channels is sparse, as most evidence is derived from the cell body of DRG neurons. Besides the pentameric ligand-gated ionotropic $\mathrm{GABA}_{\mathrm{A}}$ and glycine receptors, the large class of $\mathrm{Cl}^{-}$channels and transporters comprises several structurally unrelated families. These include $\mathrm{Ca}^{2+}$-activated $\mathrm{Cl}^{-}$channels of the anoctamin (Ano or TMEM16), bestrophin (Best) and tweety homolog (Ttyh) families, the CLC channel/transporter family, the cystic fibrosis transmembrane conductance regulator (CFTR), volume-regulated anion channels (VRAC) that are formed by LRRC8 proteins, and SLCO2A1 as the molecular correlate of maxi-anion channels. Of those, GABA A, Ano1, Best1, Thyh1, CLC-3 and CLC- 6 have been associated with nociception: either their expression is altered in pain states or their activity modulates pain (see Figure 1, marked in red), however other candidates may also contribute and can be addressed by an increasing number of genetic, chemogenetic, optogenetic and pharmacological tools (Bormann, 2000; Enna and McCarson, 2006; Poet et al., 2006; Boudes et al., 2009; Zeilhofer et al., 2009; Liu et al., 2010; Cho et al., 2012).

\section{Ligand-Gated Chloride Channels $\mathrm{GABA}_{\mathrm{A}}$ Receptors}

$\gamma$-aminobutyric acid (GABA) is the main inhibitory neurotransmitter of the central nervous system (Olsen, 2002). It binds to two different receptor types, the ionotropic $\mathrm{GABA}_{\mathrm{A}}$ receptors and the metabotropic $\mathrm{Gi} /$ o protein-coupled $\mathrm{GABA}_{B}$ receptors. $\mathrm{GABA}_{\mathrm{A}}$ receptors are members of the Cys-loop receptor family of ligand-gated ion channels that share a pentameric structure with a large $\mathrm{N}$-terminal extracellular domain for ligand binding, four transmembrane regions including the pore-forming segment, and one large cytoplasmic loop for intracellular modifications (Galaz et al., 2015). To date 19 different subunits have been identified (six $\alpha$-, three $\beta$-, three $\gamma$-, three $\rho$ - and one of each $\varepsilon^{-}, \delta$-, $\theta$-, and $\pi$-subunits) (Sigel and Steinmann, 2012). The major GABA $\mathrm{A}$ channel isoform in adult DRG neurons is composed of two $\alpha 1$ - and $\beta 2$-subunits and one $\gamma 2$-subunit (Sigel and Steinmann, 2012). Alternative subunit assemblies define different functional and physiological properties.

GABA has been implicated as an important modulator at different levels of the pain pathway, although mainly microcircuitries within the spinal dorsal horn (SDH) and supraspinal brain regions have been investigated (Enna and McCarson, 2006). Already in the 1970s it was established that primary sensory neurons respond to GABA stimulation with depolarization (De Groat et al., 1972). Since then, a multitude of studies link this enigmatic response to a possible chloride conductance (Desarmenien et al., 1979, 1980, 1981; Gallagher et al., 1983a,b). In embryonic DRG neurons, GABA generates an inward current, which is inhibited by the $\mathrm{GABA}_{\mathrm{A}}$ antagonists bicuculline, picrotoxin and TBPS (Valeyev et al., 1999). The attributes of these GABA-induced currents depend on the primary afferent cell type, with TTX-sensitive and capsaicin-insensitive neurons generating larger currents than capsaicin-sensitive nociceptors (White, 1990). Accordingly, unique developmental expression patterns of different $\mathrm{GABA}_{\mathrm{A}}$ subunits are reported: $\alpha 2$ and $\beta 3$ subunit mRNA is expressed in all embryonic and adult DRG neurons, while $\beta 2 \mathrm{mRNA}$ is only present in adult ones; $37 \%$ of DRG neurons express the GABA $\mathrm{A} \gamma$-subunit (Furuyama et al., 1992; Maddox et al., 2004); GABA subunits $\alpha 1, \alpha 6, \beta 1, \gamma 2 \mathrm{~L}$, and $\rho 2$ are absent in DRG, and the $\delta$-subunit is only weakly expressed (Ma et al., 1993; Maddox et al., 2004; Du et al., 2017).

By now, a role for $\mathrm{GABA}_{\mathrm{A}}$-mediated currents has been established in all morpho-functional nociceptor compartments, where they have different roles in pain regulation and distinct GABA sources: GABA released at an injury site sensitizes nociceptors at the peripheral terminal, while GABA acting in a paracrine mode on the cell bodies within the DRG has mostly antinociceptive effects (Du et al., 2017). GABA $\mathrm{A}$ responses can be evoked both in the dorsal root as well as in the sciatic nerve, demonstrating the presence of these receptors on the central and peripheral axon (Bhisitkul et al., 1987). GABA $\mathrm{A}$ receptors located at central terminals of primary afferents in the spinal dorsal horn respond to GABA-release from spinal interneurons and induce presynaptic inhibition of synaptic inputs, which in most sensory systems is responsible for contrast enhancement and gain control (Zimmerman et al., 2019). Activation of these $\mathrm{GABA}_{\mathrm{A}}$ receptors by GABA released at axo-axonic synapses induces $\mathrm{Cl}^{-}$efflux that causes primary afferent depolarization. Paradoxically, this depolarization leads to a reduced transmitter release from afferent terminals by either shunting inhibition, inactivation of voltage-gated $\mathrm{Na}^{+}$channels or inactivation of voltage-gated $\mathrm{Ca}^{2+}$ channels and is thus antinociceptive (Rudomin and Schmidt, 1999; Kullmann et al., 2005; Lidierth, 2006; Witschi et al., 2011). Sensory afferents synapse to different dorsal horn inhibitory GABA interneurons that are further modulated by descending projections from cortex and brainstem. These interneurons then affect the transmission of painful signals from the nociceptor to the secondary neuron. Loss of presynaptic, 


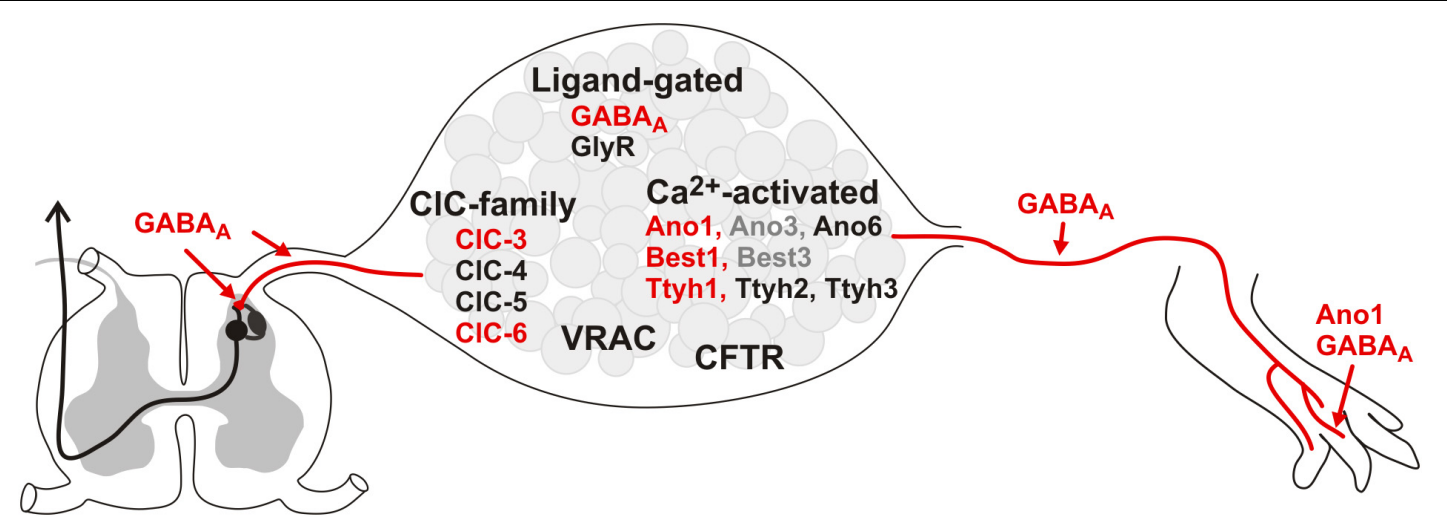

FIGURE 1 | $\mathrm{Cl}^{-}$conductances expressed in DRGs. Expression of the depicted $\mathrm{Cl}^{-}$channels/transporters has been demonstrated in DRGs. The channels in red have been associated with pain: Their activity in nociceptors affects pain sensation and/or their expression is modulated in primary afferents in pain conditions. In contrast, for the conductances written in black neither a clear contribution to pain behavior, nor a regulation in pain models has been demonstrated so far. The gray candidates show low expression and no particular role in nociceptors has been assigned to them yet. As most data exists on the mRNA/protein level within the DRG, little is known about the distribution of the $\mathrm{Cl}^{-}$conductances within the central or peripheral axons and their terminals. So far, only Ano1 and GABA $A$ have been functionally established at the peripheral axon terminal, while $\mathrm{GABA}_{\mathrm{A}}$ is also involved in presynaptic inhibition of the primary afferents in the dorsal horn of the spinal cord.

$\mathrm{GABA}_{\mathrm{A}}$-mediated inhibition leads to tactile hypersensitivity and impaired texture discrimination (Zimmerman et al., 2019). The descending projections can set pain thresholds based on internal and emotional states, with acute stress and expected pain producing analgesia, while chronic stress and anxiety facilitate pain (Porreca et al., 2002; Basbaum et al., 2009; Jennings et al., 2014; Francois et al., 2017). The main source for descending pain modulation is the rostroventral medulla (RVM), which harbors both glutamatergic $\mathrm{ON}$ neurons that facilitate nociception by excitation of primary afferent terminals and/or excitatory neurons within SDH (Heinricher et al., 2009) and antinociceptive OFF cells that provide inputs onto nociceptive primary afferents and thus suppress pain transmission (Budai and Fields, 1998). Interestingly, the majority of RVM-derived descending input is GABAergic, with indirect GABAergic projections via $\mathrm{SDH}$ GABAergic interneurons that, when inhibited, lead to mechanical hyposensitivity (Francois et al., 2017), as well as GABAergic inputs to sensory afferents that, when inhibited, increase both heat and mechanical sensitivity (Zhang et al., 2015).

In inflamed tissue, blood and immune cells actively release GABA, which may directly act on primary afferent nerve terminals and induce excitation and sensitization (Bhat et al., 2010; Bravo-Hernandez et al., 2014). The GABA A subunits $\alpha 1$ and $\beta 2 / 3$ have been detected by immunohistochemistry in 10 $14 \%$ of unmyelinated peripheral axons in the cat glabrous skin (Carlton et al., 1999). Peripheral administration of the selective $\mathrm{GABA}_{\mathrm{A}}$ receptor agonist muscimol evokes nocifensive behavior whereas the $\mathrm{GABA}_{\mathrm{A}}$ blockers picrotoxin or bicuculline inhibit formalin-induced pain-like behavior (Bravo-Hernandez et al., 2014; Jang et al., 2017). GABA-activated currents are modified by inflammatory mediators, like prostaglandin $\mathrm{E} 2\left(\mathrm{PGE}_{2}\right)$, bradykinin, histamine, ATP or interferon gamma (Sokolova et al., 2001; Vlachova et al., 2001; Labrakakis et al., 2003; Vikman et al., 2003; Toulme et al., 2007). The neurotransmitter serotonin (5-HT) or a $5-\mathrm{HT}_{2}$ receptor agonist potentiate, while dopamine
D1 receptor agonists, $N$-methyl-D-aspartate (NMDA) - but not kainic acid - as well as adenosine and caffeine inhibit GABA currents in DRG neurons (Xi and Akasu, 1996; Hu and Li, 1997; Li et al., 2004). Likewise, neuropeptides such as substance $\mathrm{P}$, neurokinin $\mathrm{A}$, and neurokinin $\mathrm{B}$ inhibit $\mathrm{GABA}_{\mathrm{A}}$-induced currents, likely mediated by protein kinase $C$, but not protein kinase A (Guan et al., 1994; Wu et al., 1994; Yamada and Akasu, 1996; Akasu and Yamada, 1997; Yang et al., 2003; Si et al., 2004; Li L. et al., 2015).

Thus, sustained inflammation or neuropathic alterations appear to strongly affect the function and expression of GABA currents and receptors. Twenty-four hours after complete Freund's adjuvant (CFA)-induced inflammation, retrogradely-labeled DRG neurons innervating the inflamed knee joint show increased GABA sensitivity and a decreased AP threshold (Chakrabarti et al., 2018). Following nerve ligation or chronic constriction injury, GABA-induced conductances and depolarization in small, medium, and large DRG neurons are attenuated (Bhisitkul et al., 1990; Chen et al., 2014; Ran et al., 2014). This is accompanied by respective downregulation of the $\mathrm{GABA}_{\mathrm{A}} \alpha 2$-subunit by $30 \%$ in ipsilateral DRGs and reduction of the number of $\gamma 2$-subunit mRNA expressing neurons (Obata et al., 2003; Obradovic et al., 2015). Consequently, injections of the GABA agonists muscimol or gaboxadol into the DRG immediately after nerve injury attenuate, whereas the GABA antagonists bicuculline or picrotoxin aggravate pain-like behavior (Naik et al., 2008, 2012; Ran et al., 2014). Upregulation of endogenous GABA within the sensory ganglion via GABA uptake inhibition alleviates thermal hyperalgesia, whereas knockdown of the $\alpha 2$ subunit further decreases pain thresholds (Obradovic et al., 2015). In contrast to the reduction of GABA currents described so far, GABA-induced conductances increase in axotomized cutaneous neurons and this is attenuated by BDNF, whereas NGF has no effect (Oyelese and Kocsis, 1996; Oyelese et al., 1997). DRG neuron cultures, which to a 
certain extent represent an axotomy model per se, also develop increased $\mathrm{GABA}_{\mathrm{A}}$ current densities with time in culture (Lee et al., 2012). Other pain models such as formalin or reserpine injections are associated with upregulated $\alpha 5 \mathrm{mRNA}$ and protein expression in DRGs and spinal cord, and peripheral or intrathecal administration of an $\alpha 5$ antagonist prevents and reverses mechanical hypersensitivity (Bravo-Hernandez et al., 2016; De la Luz-Cuellar et al., 2019). Albeit there is an increasing body of data, the contribution of $\mathrm{GABA}_{\mathrm{A}}$ receptors in nociceptors to pathological pain is still controversial.

\section{Glycine Receptors}

The ligand-gated ionotropic glycine receptor (GlyR) is activated by amino acid ligands, with glycine, taurine and beta-alanine being the most common agonists, whereas the alkaloid strychnine acts as a high affinity antagonist (for reviews see Lynch, 2009; Dutertre et al., 2012; Galaz et al., 2015). Four different types of alpha subunits (GlyR $\alpha 1-4$ ) and one beta subunit (GlyR $\beta$ ) form heteropentameric ion channels in a $2 \alpha: 3 \beta$ stoichiometry (Dutertre et al., 2012). Homomeric receptors composed solely of $\alpha$ subunits have been observed in recombinant expression systems whereas $\beta$ subunits are retained in the endoplasmic reticulum and are thus unable to form functional channels (Dutertre et al., 2012; Galaz et al., 2015).

The role of glycine receptors in pain modulation mainly relates to the SDH, where $\alpha 3 \beta$ heteromeric GlyRs are important anion channels of glycinergic inhibitory neurotransmission in the superficial SDH (Lynch, 2009). $\alpha 3$ subunits are mainly clustered by gephyrin at postsynaptic membranes in lamina 2 , and colocalize with $\alpha 1$ subunits in around half the cases (Harvey et al., 2004). These $\alpha 3$ containing GlyRs are phosphorylated by proteinkinase A activated downstream of $\mathrm{PGE}_{2}$ receptor $\mathrm{EP}_{2}$, thereby diminishing glycinergic inhibitory input to lamina 2 neurons (Ahmadi et al., 2002; Harvey et al., 2004). In GlyR $\alpha 3^{-/-}$ mice, this $\mathrm{PGE}_{2}$-mediated reduction of inhibitory postsynaptic potentials of lamina 2 neurons is abolished, together with alleviated pain sensitization in response to chronic peripheral inflammation, while acute inflammatory pain stimuli are not affected (Harvey et al., 2004). In addition, analgesic effects of cannabinoids in different models of chronic inflammatory and neuropathic pain are absent in these mice (Xiong et al., 2012). Tissue damage during the neonatal period decreases GlyRmediated input onto SDH GABAergic and glutamatergic neurons in adulthood and both mRNA and protein levels of the GlyR $\beta$ subunit are upregulated in spinal cord in animals subjected to prolonged pain (Li et al., 2013; Galaz et al., 2015). Thus a major role for GlyRs in SDH circuits is well documented whereas the reports on glycinergic effects on primary afferents are sparse and inconsistent. In chicken embryo DRGs, uptake of [14C]2deoxyglucose as a marker of excitatory activity is facilitated in response to glycine stimulation, and taurine - a GlyR (but also $\mathrm{GABA}_{\mathrm{A}}$ ) agonist - causes depolarizing responses in frog primary afferents (Saji and Obata, 1981; Padjen et al., 1989). In contrast, GlyRs are not involved in presynaptic modulation of transmitter release in rat spinal cord sections and neither taurine nor glycine show any detectable agonist activity in mammalian DRG neurons (Robertson, 1989; Valeyev et al., 1996, 1999; Betelli et al., 2015).
Forty four percent of all rat DRG neurons express GlyR $\beta$ subunit mRNA (Furuyama et al., 1992), L5 DRG neurons express both $\alpha 3$ and $\alpha 1$ GlyR subunits, and protein expression is decreased after intrathecal $\mathrm{PGE}_{2}$ injection (Wang et al., 2018). DRG and SDH neuron co-cultures develop inhibitory glycinergic synapses which are able to generate inhibitory synaptic transmission at DRG neurons (Shypshyna and Veselovs'kyi, 2010). This suggests that GlyR in primary afferent neurons are predominantly involved in setting transmission efficacy at SDH synapses but are not involved in nociceptive transduction.

\section{Calcium-Activated Chloride Channels Anoctamins}

Anol was identified in 2008 as the first member of the anoctamin protein family (Ano; TMEM16) (Caputo et al., 2008; Schroeder et al., 2008; Yang et al., 2008). This protein family consists of ten members, Ano1-10, and the recent structural data revealed ten transmembrane domains (Paulino et al., 2017). The subunits assemble as dimers with two distinct pores to serve divers functions ranging from calcium level regulation to lipid scramblase and ion channel activity (Caputo et al., 2008; Schroeder et al., 2008; Yang et al., 2008; Pifferi et al., 2009; Wanitchakool et al., 2017). Alternative splicing further increases the number of isoforms with different biophysical properties and expression (Ferrera et al., 2009; Mazzone et al., 2011; Ertongur-Fauth et al., 2014). Ano1, 2, and 6 have been shown to convey $\mathrm{Ca}^{2+}$-activated $\mathrm{Cl}^{-}$conductances, although Ano6 can conduct both anions and cations depending on intracellular $\mathrm{Ca}^{2+}$ concentration and membrane potential (Caputo et al., 2008; Schroeder et al., 2008; Yang et al., 2008; Pifferi et al., 2009; Ye et al., 2019). Ano conductances are synergistically regulated by intracellular $\mathrm{Ca}^{2+}$, membrane depolarization, membrane lipids and heat (Cho et al., 2012; Schreiber et al., 2018; Le et al., 2019; Lin et al., 2019). The $\mathrm{Ca}^{2+}$ sensitivity represents a hallmark of Ano function: Cryo-EM structures of mouse Anol reveal two $\mathrm{Ca}^{2+}$ binding sites within the inner vestibule of the hour-glass shaped pore (Paulino et al., 2017). $\mathrm{Ca}^{2+}$ binding leads to conformational changes particularly in the $\alpha 6$ transmembrane domain rendering the pore conductive (Paulino et al., 2017). The $\mathrm{Ca}^{2+}$ sensitivity is dependent on membrane voltage and temperature and varies strongly between the different splice variants ranging from approximately 100 to $400 \mathrm{nM}$ for Ano1 and from $<1 \mu \mathrm{M}$ up to $100 \mu \mathrm{M}$ for Ano6 (Ferrera et al., 2009; Grubb et al., 2013; Ertongur-Fauth et al., 2014; Strege et al., 2015; Lin et al., 2019). In native cells, the organization of Ano1 in microdomains/signaling complexes together with caveolin-1 allows for very specific signaling downstream of $\mathrm{Ca}^{2+}$, despite the various sources of this ion, like TRP channels, voltage-gated calcium channels (VGCCs), Inositol-1,4,5-trisphosphate $\left(\mathrm{IP}_{3}\right)$-receptors on the endoplasmic reticulum, or store-operated calcium entry (Jin et al., 2013, 2016). In nociceptors, Ano1 is specifically activated by local $\mathrm{Ca}^{2+}$ signals mediated by TRPV1 and inflammatory mediators like serotonin or bradykinin via G-protein coupled receptors (GPCRs) activating the $\mathrm{IP}_{3}$-receptor cascade (Liu et al., 2010; Jin et al., 2013; Salzer et al., 2016) (see Figure 2). This activation of Ano1 has not only been demonstrated at the soma by electrophysiological recordings, but was also shown 
in behavioral tests, confirming its functional importance at the peripheral nerve ending (Liu et al., 2010). Ano1 channels localize to microdomains in the membrane and interact with the GPCR and $\mathrm{IP}_{3} \mathrm{R}$ (Jin et al., 2013). This compartmentalization is lipid raft-dependent and might (1) allow for a sufficient local $\mathrm{Ca}^{2+}$ concentration for channel activation and (2) shield Ano1 from global $\mathrm{Ca}^{2+}$ waves (Jin et al., 2013, 2016). This may impede the direct translation of results obtained from expression systems to native cells and vice versa. Furthermore, the loop between transmembrane domain 2 and 3, which is involved in forming the bradykinin/ $/ \mathrm{IP}_{3}$-receptor signaling unit, contains two differentially-spliced segments (Ferrera et al., 2009; Jin et al., 2013). In nociceptors neither the expression pattern of the splice variants nor the potential regulation of splicing in (chronic) pain states have been analyzed, but might affect the interaction of the anoctamins with other proteins as well as their $\mathrm{Ca}^{2+}$-sensitivity and thus bear an additional mode of channel regulation. Anoctamin channel activity also responds to changes in the membrane environment: upon heterologous expression, inhibition of phospholipase $A_{2}$ suppresses human Ano1- and Ano6-mediated currents (Schreiber et al., 2018). Furthermore, binding of the phospholipid phosphatidylinositol4,5-bisphosphate $\left(\mathrm{PIP}_{2}\right)$ is necessary for Anol channel activity under submaximal $\mathrm{Ca}^{2+}$ conditions, while it prevents fast channel desensitization under $\mathrm{Ca}^{2+}$ saturation (Le et al., 2019). Activation of Gq-PCR could thus activate Ano1 via $\mathrm{Ca}^{2+}$-release from the endoplasmic reticulum by $\mathrm{IP}_{3}$, but would counteract Anol activation due to PIP $_{2}$ depletion (Le et al., 2019). This is of particular interest in chronic pain states, because $\mathrm{PIP}_{2} / \mathrm{Ca}^{2+}$. signaling is altered under these conditions demonstrated by elevated $\mathrm{IP}_{3}$-levels in chronic constriction injury of the sciatic nerve (Zhang et al., 2018).

This complex activation points to two roles of Ano channels in nociceptors: Firstly, they serve as primary sensory channels to detect noxious heat (Cho et al., 2012), and secondly, they are involved in the amplification of intracellular signals affecting membrane voltage (Jin et al., 2013). mRNA of all three anoctamins is expressed in mouse and human trigeminal and dorsal root ganglia (Boudes et al., 2009; Flegel et al., 2015). Ano1 is found primarily in small-diameter nociceptors and upregulated in formalin and neuropathic pain models and associated with increased excitability of sensory neurons (Yang et al., 2008; Liu et al., 2010; Cho et al., 2012; Jin et al., 2013; García et al., 2014; Deba and Bessac, 2015; Pineda-Farias et al., 2015; Takayama et al., 2015; Zhang et al., 2018; Chen et al., 2019). Depletion of Anol increases the response latency of mice to noxious heat stimuli and this stresses the importance of Anol as a physiological heat sensor (Cho et al., 2012). However, Anol does not only complement the role of TRPV1 due to their redundant function as a primary temperature sensor, but also associates with TRPV1 channels and thus amplifies TRPV1-mediated currents in expression systems and DRG neurons (Takayama et al., 2015) (see Figure 2). This coupling between TRPV1 and Anol also seems to be relevant in vivo: Activation of Anol induces nocifensive behavior in mice, although this effect could be largely due to direct TRPV1 activation (Deba and Bessac, 2015; Liu et al., 2016). Pharmacological inhibition or conditional knockout of Anol alleviates thermal and mechanical hyperalgesia both in neuropathic and inflammatory pain models (Lee et al., 2014; Pineda-Farias et al., 2015; Chen et al., 2019).

A

extracellular

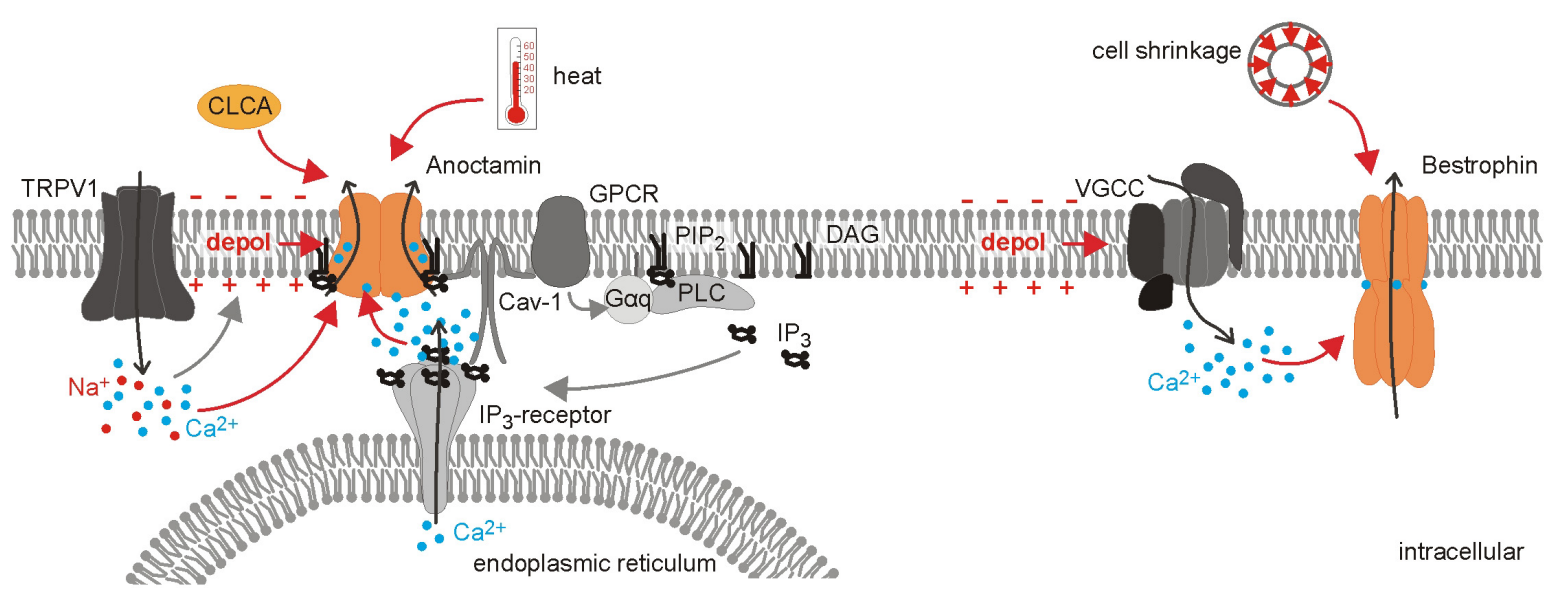

FIGURE 2 | Differential activation of $\mathrm{Ca}^{2+}$-gated $\mathrm{Cl}^{-}$channels in nociceptors. Overview of the distinct regulation of the $\mathrm{Ca}^{2+}$-gated $\mathrm{Cl}^{-}$channels anoctamin and bestrophin. (A) Ano1 is found in a signaling complex together with GPCR, Caveolin-1 (Cav-1) and the Inositol-1,4,5 trisphosphate (IP $\left.{ }_{3}\right)$ receptor in the membrane of the endoplasmic reticulum. This proximity of signaling molecules allows for a localized $\mathrm{Ca}^{2+}$ rise which is sufficient to activate the $\mathrm{Cl}^{-}$channel $\mathrm{Ano1}^{2}$, while the $\mathrm{Ca}^{2+}$ increase mediated by VGCCs does not affect anoctamin currents. Binding of phosphatidylinositol-4,5-bisphosphate $\left(\mathrm{PIP}_{2}\right)$ to anoctamin is necessary for channel opening under low $\mathrm{Ca}^{2+}$ concentration and prevents channel desensitization when $\mathrm{Ca}^{2+}$ concentration is high. Ano1 is further activated by heat and membrane depolarization. Direct interaction of TRPV1 and Ano1 leads to subsequent activation of anoctamin mediated by the TRPV1-induced depolarization and Ca ${ }^{2+}$ influx. Ano1 and TRPV1 act as peripheral heat sensors, but whether the full signaling complex exists at the peripheral nerve terminals has not been unequivocally shown so far. Additionally, the soluble N-terminus of chloride channel accessory (CLCA) increases surface availability of anoctamin. (B) In contrast to anoctamin, bestrophins can be activated by the $\mathrm{Ca}^{2+}$ influx through VGCCs and cell shrinkage. 


\section{Bestrophins}

Four members of the Bestrophin family, Best1-4, have been identified in humans and three paralogs are found in mice (Hartzell et al., 2008). The X-ray structure of the chicken and bacterial bestrophin paralog has revealed that the subunits assemble as homo- or heteropentamers forming a central pore, which can conduct anions as large as glutamate and GABA (Sun et al., 2002; O'Driscoll et al., 2008, 2009; Park et al., 2013; Bharill et al., 2014; Kane Dickson et al., 2014; Yang et al., 2014). Both cell volume as well as intracellular $\mathrm{Ca}^{2+}$ regulate the largely voltage-independent bestrophin currents: cell shrinkage by hyperosmotic solution inhibits hBest 1 and mBest 2 by $50-$ $70 \%$, while cell swelling causes a smaller and less robust current increase (Fischmeister and Hartzell, 2005). The channel displays a high $\mathrm{Ca}^{2+}$ sensitivity $\left(\mathrm{EC}_{50} \sim 150-200 \mathrm{nM}\right)$, which renders it partially conductive under resting $\mathrm{Ca}^{2+}$ conditions, and can be activated by VGCCs (Hartzell et al., 2008; O'Driscoll et al., 2008; Boudes et al., 2009; Lee et al., 2010). As for anoctamins, the $\mathrm{Ca}^{2+}$ sensitivity of bestrophins is attributable to direct interaction of the divalent cation with an acidic amino acid cluster below the membrane-cytosol interface found in each subunit (Kane Dickson et al., 2014; Paulino et al., 2017). This $\mathrm{Ca}^{2+}$-clasp is formed by the proximal C-terminus and the $\mathrm{N}$-terminus of the adjacent subunit (Kane Dickson et al., 2014). Interestingly, a splice variant of Best1 lacking the conserved $\mathrm{N}$-terminal domain, including the first transmembrane domain, still produces a $\mathrm{Cl}^{-}$conductance that is activated by $\mathrm{Ca}^{2+}$ when heterologously expressed (Kuo et al., 2014). Just as for Best1, several splice variants are also known for Best3 (Golubinskaya et al., 2019). The role of bestrophins in nociception has not been fully established yet, but both Best1 and Best3 mRNA are detected in mouse DRGs and Best1 mRNA and protein expression is shown in rat DRGs (Al-Jumaily et al., 2007; Boudes et al., 2009; Pineda-Farias et al., 2015). Expression of bestrophin and the corresponding conductance seems to be limited to medium-sized DRG neurons (André et al., 2003). Upregulation of Best1 in mice after sciatic nerve transection is compensated for in Best1 knockout animals by upregulation of Best3 (Boudes et al., 2009). Although an increase in Best1 expression is not observed after spinal nerve ligation in rats, intrathecal injection of Best1 antibody reduces Best1 protein in DRG and spinal cord and attenuates spinal nerve ligationinduced tactile allodynia, indicating a contribution of bestrophin to neuropathic pain (Pineda-Farias et al., 2015). In addition to the regulation of bestrophins themselves, these channels may be affected by altered $\mathrm{Ca}^{2+}$ signaling in nociceptors, for example as a consequence of VGCC upregulation in inflammation (Bourinet and Zamponi, 2005).

\section{Tweety-Homolog}

Three genes, Ttyh1-3, form the $\mathrm{Ca}^{2+}$-activated Tweety-homolog $\mathrm{Cl}^{-}$channel family and strong mRNA expression of all three members is detected in mouse and human trigeminal ganglia and DRG (Flegel et al., 2015). Each member is sufficient to produce a swelling-induced volume-regulated $\mathrm{Cl}^{-}$conductance (VRAC $\mathrm{Cl}_{\text {,swell }}$ ) with very similar properties to native $\mathrm{VRAC}_{\mathrm{Cl} \text {,swell }}$ which is predominantly found in astrocytes (Han et al., 2019).
However, Ttyh2 and Ttyh3 have originally been introduced as $\mathrm{Ca}^{2+}$-sensitive channels with a large single-channel conductance, while only the C-terminally spliced Ttyh1 is activated in a $\mathrm{Ca}^{2+}$ independent fashion by hypertonic solution (Suzuki and Mizuno, 2004). The outwardly rectifying native $\mathrm{VRAC}_{\mathrm{Cl} \text {, swell }}$ current with significant glutamate permeability is independent of $\mathrm{Ca}^{2+}$, but sensitive to inhibitors for tyrosine kinase and mitogen-activated protein kinase (Han et al., 2019). Therefore, the assignment of tweety homologs to $\mathrm{Ca}^{2+}$-activated, volume-activated or even Maxi-chloride conductances is inconsistent and needs further investigation. Of note, Ttyh1 is downregulated in DRGs after sciatic nerve transection (Al-Jumaily et al., 2007; Boudes et al., 2009; Flegel et al., 2015). However, since RNA-sequencing of mouse cerebral cortex revealed stronger expression of Ttyh1 and 3 in astrocytes compared to neurons, while expression of Ttyh2 in neurons is very low but rather appears in oligodendrocytes, it can be assumed that the high expression in DRGs is attributable to a function in non-neuronal cells rather than a relevant anion conductance in nociceptors (Zhang et al., 2014).

\section{Chloride Channel Accessory (CICA)}

Chloride channel accessory has previously been described as another distinct family of $\mathrm{Ca}^{2+}$-activated $\mathrm{Cl}^{-}$channels with four orthologs identified in humans and eight orthologs in mice, of which one might be a pseudogene (Gandhi et al., 1998; Gruber et al., 1998, 1999; Evans et al., 2004; Loewen and Forsyth, 2005; Patel et al., 2009). Yet, based on bioinformatic analysis, further studies revealed that ClCA genes encode soluble proteins with or without a transmembrane domain or GPI anchor that do not yield a $\mathrm{Cl}^{-}$conductance per se, but rather modulate other $\mathrm{Cl}^{-}$ channels (Gibson et al., 2005; Mundhenk et al., 2006; Patel et al., 2009). Secreted ClCA1 enhances Anol surface expression which in turn leads to increased current density (Sala-Rabanal et al., 2015) (see Figure 2). mRNA transcripts of ClCA1, 2, 3, and 5 are expressed in mouse DRGs, and ClCA5 is downregulated after axotomy (Al-Jumaily et al., 2007; Imhof et al., 2011). In contrast, a 1724-fold increase of ClCA3 mRNA transcripts is found after induction of inflammatory pain in an antigen-induced model for arthritis, but a role for this protein could so far not be corroborated in a follow-up study, where ClCA3 knockout mice show a minor reduction in joint swelling but no pain phenotype (Ebbinghaus et al., 2014). Nonetheless, CICAs may be functional regulators of nociception due to their paracrine modulation of other $\mathrm{Cl}^{-}$channels in neighboring neurons in the DRG and thus deserve to be further addressed.

\section{CLC Family of Chloride Channels and Transporters}

Jentsch et al. (1990) cloned the first voltage-gated $\mathrm{Cl}^{-}$channel from Torpedo, CLC-0, as the founding member of the CLC family and only one year later they identified and characterized the first mammalian homolog from rat skeletal muscle (Steinmeyer et al., 1991). To date, the mammalian CLC family comprises nine members that can be subdivided into plasma membrane $\mathrm{Cl}^{-}$ channels (CLC-1, CLC-2, CLC-Ka, and CLC-Kb) and secondary active $2 \mathrm{Cl}^{-} / \mathrm{H}^{+}$exchangers (CLC-3, CLC-4, CLC-5, CLC-6, and CLC-7). They are generally located within intracellular 
(lysosomal and endosomal) membranes. CLC family members have $18 \alpha$-helices located within the membrane and share homodimeric co-assembly into functional channels/transporters, with one ion conduction path per subunit (Jentsch and Pusch, 2018). Some members (CLC-2, CLC-3, CLC-5, and CLC-7) are widely expressed whereas others exhibit strict tissue-specific expression (Jentsch et al., 2005; Jentsch and Pusch, 2018). Lumbar DRGs of mice express mRNA transcripts encoding CLC-3, CLC-4, CLC-5, and CLC-6 (Qi et al., 2018) and protein expression in DRGs is demonstrated for CLC-3 and CLC-6 (Poet et al., 2006; Pang et al., 2016). Only few studies address the importance of CLC proteins in the peripheral nervous system, but these demonstrate that CLC proteins are utterly important for determining excitability of DRG neurons under (patho)physiological conditions.

\section{CLC-3 and CLC-5}

CLC-3 is expressed in both isolectin-B4-binding (IB4) nonpeptidergic, and peptidergic nociceptors (Bali et al., 2013; Pang et al., 2016). Although resting membrane potentials and voltagedependent currents are unaltered after knockout or knockdown of CLC-3 and CLC-5, ablation of CLC-3 increases the excitability of DRG neurons as indicated by decreased AP thresholds and decreased rheobase (Pang et al., 2016; Qi et al., 2018). This is in line with the hypersensitivity to mechanical sensory stimulation in neuropathic and tumor pain models in rodents with a knockdown or genetic knockout of CLC-3 (Bali et al., 2013; Pang et al., 2016). Furthermore, CLC-3 and CLC-5 are involved in the downstream signaling of the biologically active sphingolipid S1P (Pang et al., 2016; Qi et al., 2018). S1P is released by platelets after surgery, trauma or blood vessel damage and induces nocifensive behavior in animal models in vivo and signatures of nociceptor activation in humans (Zhang et al., 2006; Mair et al., 2011; Camprubi-Robles et al., 2013; Li C. et al., 2015). As the cellular mechanisms underlying these S1P effects, we found that S1P directly depolarizes nociceptors through an excitatory inward current, which is significantly attenuated by siRNA-mediated CLC-3 or CLC-5 knockdown (Camprubi-Robles et al., 2013; Qi et al., 2018). The acute excitation of nociceptive neurons and the activation of CLC transporters involve S1P receptor type $3\left(\mathrm{~S}_{1} \mathrm{PR}_{3}\right)$-dependent activation of the Rho GTPase signaling cascade, however, not Rho-associated protein kinase (ROCK) (Camprubi-Robles et al., 2013; Quarta et al., 2017; Qi et al., 2018; Kalpachidou et al., 2019). Importantly, these studies not only establish a role of CLC-3 and CLC- 5 transporters in nociception, but whole-cell patch-clamp recordings also provide evidence that they affect conductances in the plasma membrane of neurons (Camprubi-Robles et al., 2013; Pang et al., 2016; Qi et al., 2018). Currently there is no data available whether CLC-3 and CLC-5 interact with accessory proteins and partially locate to the plasma membrane as found for certain splice variants in heterologous expression systems, or induce another $\mathrm{Cl}^{-}$conductance (Kawasaki et al., 1995; Huang et al., 2001; Okada et al., 2014; Guzman et al., 2015; Jentsch and Pusch, 2018). After spared nerve injury, CLC-3 mRNA and protein levels surprisingly decrease in lumbar DRGs (Pang et al., 2016). In contrast to its acute excitatory action, the persisting suppression of CLC-3 expression correlates well with mechanical hypersensitivity which is rescued through intrathecal delivery of CLC-3 adenoviral vector (Pang et al., 2016). CLC3 mRNA expression is also significantly reduced in DRGs in a cancer pain model, and siRNA knockdown of CLC-3 in DRGs further increases tumor-induced mechanical hyperalgesia (Bali et al., 2013).

\section{CLC-6}

CLC-6 is a $2 \mathrm{Cl}^{-} / \mathrm{H}^{+}$exchanger in the membrane of (late) endosomes almost exclusively expressed in the nervous system (Poet et al., 2006). Its abundance is exceptionally high in trigeminal ganglia, DRGs and spinal cord suggesting a relevance of the transporter in the somatosensory system (Poet et al., 2006). Mice with a global depletion of CLC-6 exhibit dramatically increased tail-flick latencies in response to painful stimuli indicating severe deficits in nociception (Poet et al., 2006). As CLC-6 deficient mice do not show significant loss of neurons and only moderate other behavioral deficits, the nociceptive deficits most likely appear to be related to a disruption of neuronal functions through intracellular lysosomal deposition (Poet et al., 2006). However, the pathophysiological mechanisms causing the prominent impairment of nocifensive behavior caused by genetic deletion of CLC-6 are currently not understood.

\section{Cystic Fibrosis Transmembrane Conductance Regulator (CFTR)}

Cystic fibrosis (CF) is a life-limiting autosomal recessive disorder caused by mutations in the gene encoding CFTR. CFTR is a member of the family of ATP binding cassette transporters, but is an anion channel that hydrolyzes ATP during the transport cycle of anions (e.g., $\mathrm{Cl}^{-}, \mathrm{HCO}_{3}{ }^{-}$), i.e., $\mathrm{CFTR}$ is an ATP-gated anion channel allowing for $\mathrm{Cl}^{-}$flux along the electrochemical gradient (reviewed in Hwang and Kirk, 2013). CF-associated mutations mostly reduce CFTR channel function, giving rise to a multiplicity of symptoms in several organ systems and severe respiratory disease that is the major cause of death of CF patients. Although the main CF disease strains are non-neuronal, relevance of CFTR in neurons has been proposed for years, as the channel is expressed in the central and peripheral nervous system of several species, including rodents, pigs and humans (Mulberg et al., 1994, 1995, 1998; Rogan et al., 2010; Kanno and Nishizaki, 2011; Reznikov et al., 2013; Marcorelles et al., 2014; Reznikov, 2017). CFTR may be exclusively expressed in neurons but not glial cells in humans (Guo et al., 2009; Niu et al., 2009; Marcorelles et al., 2014). Importantly, evidence for CFTRmediated anionic currents is not available for most cell types. However, there are some indications for functional expression of CFTR in DRG neurons and for its relevance in the development of mechanical allodynia (Kanno and Nishizaki, 2011). Indirect evidence suggests that noradrenalin may stimulate ATP release through CFTR after $\beta 3$-adrenergic receptor stimulation as a mechanism to promote neuropathic pain (Kanno et al., 2010; Kanno and Nishizaki, 2011). Following activation of AMPA receptors in cultured spinal cord microglia, ATP release is strongly attenuated by pharmacological inhibition and genetic knockout of CFTR, indicating that CFTR may contribute to ATP 
release in spinal cord and probably also in DRGs (Liu et al., 2006; Kanno and Nishizaki, 2011). However, currently it is unknown whether these mechanisms are relevant for pain processing in nociceptors despite the undoubted significance of purinergic signaling in the entire pain pathway (e.g., Jahr and Jessell, 1983; reviewed in Burnstock, 2013). Functional, biophysical and pharmacological properties of CFTR in DRG and spinal cord neurons/glia remain elusive at present and pain phenotypes have not been conclusively reported in CF patients.

\section{Volume-Regulated Anion Channels (VRAC or VSOAC)}

VRAC, also referred to as volume-sensitive organic osmolyte anion channel (VSOAC), mediates fluxes of anions and organic osmolytes (e.g., amino acids and their derivatives or methylamines). The channels accordingly control regulatory volume decrease (RVD) to compensate for cell swelling, changes of tonicity or intracellular ionic strength (for a comprehensive review see Jentsch et al., 2016). LRRC8 family members are the molecular correlates of VRAC, and LRRC8A constitutes an essential subunit which co-assembles with one or more other LRRC8 member(s) to give rise to VRAC (Qiu et al., 2014; Voss et al., 2014). DRG neurons express mRNA transcripts encoding LRRC8A and a VRAC current can be induced both by hypotonic extracellular solution as well as by hypertonic pipette solution suggesting that LRRC8A contributes to VRAC in DRG neurons, albeit a role in nociception has not been shown unequivocally (Wang et al., 2017; Liu et al., 2019). Interestingly, $\mathrm{Ca}^{2+}$-activated $\mathrm{Cl}^{-}$channels might contribute to VRAC: Anol can also be activated by cell swelling and members of the tweety-homolog family (see $\mathrm{Ca}^{2+}$-activated $\mathrm{Cl}^{-}$channel section) constitute essential subunits for swelling-induced VRAC in cultured cortical astrocytes (Han et al., 2019; Liu et al., 2019). As mRNA transcripts encoding Ttyhl/2/3 are apparently abundant in lumbar DRGs, and as expression levels of Ttyh 1 appear to be slightly regulated in axotomized DRG neurons, it is tempting to speculate that tweety proteins may contribute to VRAC currents in DRG neurons (L4/L5; Al-Jumaily et al., 2007; Boudes et al., 2009). However, functional expression of these proteins has not been explored in the somatosensory system yet.

\section{Maxi-Anion Channels (Also Maxi-Cl- Channels)}

Maxi-anion channels (MACs) exhibit extraordinarily large unitary conductances (200-500 pS), and probably are ubiquitously expressed in virtually every cell type (reviewed in Sabirov et al., 2016). Apart from providing transfer routes for anions, MACs mediate release pathways for ATP and are associated with purinergic signaling (e.g., Bell et al., 2003; Sabirov and Okada, 2005). In resting cells, MACs are usually inactive, but can be activated by a multitude of stimuli including cell stress (osmotic, ionic strength, mechanical, heat, oxidation, etc.). Further, MAC activity is modulated in context of GPCR signaling through several ligands such as endothelin-1, adenosine, and bradykinin, and inhibited by $\mathrm{PGE}_{2}$ (summarized in Sabirov et al., 2016, 2017). The prostaglandin transporter SLCO2A1 has been identified as the molecular correlate of MACs (Kanai et al., 1995;
Sabirov et al., 2017). As SLCO2A1/MAC activity is modulated by a large number of pain-initiating and pro-inflammatory stimuli (e.g., cell damage, ligands of GPCRs, prostaglandins, etc.) and given its involvement in purinergic signaling, these channels may be of relevance in peripheral pain mechanisms. However, the abundance and function of SLCO2A1 in the peripheral nervous system has not been addressed yet.

\section{CLINICAL POTENTIAL OF CHLORIDE CHANNELS/TRANSPORTERS FOR PAIN THERAPY}

As nociceptors are the primary sensors for noxious stimuli and the site of peripheral sensitization before subsequent changes in the entire pain pathway manifest chronification, they remain an attractive target site for pain therapies. Multiple studies demonstrate that painful conditions lead to changes in various $\mathrm{Cl}^{-}$channels, transporters and homeostasis in primary afferent nociceptors, while vice versa altered activity of $\mathrm{Cl}^{-}$channels and transporters affects pain perception. This draws attention to nociceptor chloride channels and transporters as potential target for the development of analgesic drugs. Bumetanide, a loop diuretic which targets the kidney-specific NKCC2, also prevents the accumulation of phosphorylated NKCC1 in DRGs, as well as the concomitant downregulation of KCC2 in the spinal cord, and alleviates mechanical and thermal hypersensitivity in a model for neuropathic pain (Modol et al., 2014). Similarly, compensating the CCC changes by viral delivery of KCC2 into DRG and spinal neurons reverses the depolarizing shift of the reversal potential for GABA-mediated currents and abolishes hypersensitivity induced by nerve injury (Li et al., 2016). Although these studies indicate great potential for targeting $\mathrm{Cl}^{-}$homeostasis in pain conditions, they have to be considered carefully since $\mathrm{Cl}^{-}$homeostasis mechanisms and nociceptor function may not be fully identical in rodents and humans (Funk et al., 2008; Rocha-Gonzalez et al., 2008; Zhang et al., 2018).

Besides, $\mathrm{Cl}^{-}$channels expressed in primary afferent nociceptors can be targeted for potential pain treatment. However, this is complicated first by the previously described variability of the $\mathrm{Cl}^{-}$reversal potential, which can switch the effect of $\mathrm{Cl}^{-}$channel opening from inhibitory to excitatory and thus profound control of $\mathrm{Cl}^{-}$concentration is indispensable, and second by the involvement of $\mathrm{Cl}^{-}$conductances in other physiological functions. Notably, Best1 and Ano1 play an important role in retina and secretory epithelia function, respectively (Hartzell et al., 2008; Oh and Jung, 2016). To overcome the problems of potential unwanted effects, splice variant- or subunit-specific drug development may offer promising perspectives: $\alpha 1$-sparing $\mathrm{GABA}_{\mathrm{A}}$ receptor agonists alleviate hyperalgesia induced by inflammation or chronic nerve constriction through pre- and postsynaptic action at nociceptive synapses in the SDH without a sedating effect (Knabl et al., 2008; Di Lio et al., 2011; Witschi et al., 2011). Likewise, $\alpha 3$ subunits of GlyRs moved into the focus of analgesic drug discovery, since they are targeted by cannabinoids and mediate analgesic properties. Although their primary action seems to be at the SDH, $\alpha 3$ GlyRs 
are also expressed in DRG neurons, and these might contribute to the analgesic effect (Lynch et al., 2017). Thus, $\mathrm{Cl}^{-}$channels on primary afferents can be targeted to achieve analgesia also in chronic pain conditions, but warrant further developments for pain relief in humans.

\section{SYNOPSIS}

$\mathrm{Cl}^{-}$homeostasis is tightly regulated in nociceptive primary afferents and essential for the effect of activation of $\mathrm{Cl}^{-}$channels on the excitability of these neurons. In contrast to the 'static' action of cation flux on cellular membrane potential and excitability, the $\mathrm{Cl}^{-}$reversal potential in primary afferent neurons typically lies between the resting membrane potential and the AP threshold and is subject to fluctuation during persisting pain. This can convert the normally inhibitory action of $\mathrm{Cl}^{-}$ channel opening into an excitatory one contributing to pain, allodynia, and hyperalgesia. Not only $\mathrm{Cl}^{-}$concentrations but also $\mathrm{Cl}^{-}$channels and transporters expressed in DRG neurons are deregulated in pain disorders (see Figure 1). A distinct role and mode of activation in nociceptors is already established for some

\section{REFERENCES}

Ahmadi, S., Lippross, S., Neuhuber, W. L., and Zeilhofer, H. U. (2002). PGE(2) selectively blocks inhibitory glycinergic neurotransmission onto rat superficial dorsal horn neurons. Nat. Neurosci. 5, 34-40. doi: 10.1038/ nn778

Akasu, T., and Yamada, K. (1997). Neurokinin-1 (NK1) receptors mediate tachykinin-induced depression of GABA current in bullfrog sensory neurons. Kurume Med. J. 44, 33-41. doi: 10.2739/kurumemedj .44 .33

Al-Jumaily, M., Kozlenkov, A., Mechaly, I., Fichard, A., Matha, V., Scamps, F., et al. (2007). Expression of three distinct families of calcium-activated chloride channel genes in the mouse dorsal root ganglion. Neurosci. Bull. 23, 293-299. doi: 10.1007/s12264-007-0044-8

André, S., Boukhaddaoui, H., Campo, B., Al-Jumaily, M., Mayeux, V., Greuet, D., et al. (2003). Axotomy-induced expression of calcium-activated chloride current in subpopulations of mouse dorsal root ganglion neurons. J. Neurophysiol. 90, 3764-3773. doi: 10.1152/jn.00449.2003

Bali, K. K., Selvaraj, D., Satagopam, V. P., Lu, J., Schneider, R., and Kuner, R. (2013). Genome-wide identification and functional analyses of microRNA signatures associated with cancer pain. EMBO Mol. Med. 5, 1740-1758. doi: 10.1002/ emmm.201302797

Barragan-Iglesias, P., Rocha-Gonzalez, H. I., Pineda-Farias, J. B., Murbartian, J., Godinez-Chaparro, B., Reinach, P. S., et al. (2014). Inhibition of peripheral anion exchanger 3 decreases formalin-induced pain. Eur. J. Pharmacol. 738, 91-100. doi: 10.1016/j.ejphar.2014.05.029

Basbaum, A. I., Bautista, D. M., Scherrer, G., and Julius, D. (2009). Cellular and molecular mechanisms of pain. Cell 139, 267-284. doi: 10.1016/j.cell.2009.09. 028

Bell, P. D., Lapointe, J. Y., Sabirov, R., Hayashi, S., Peti-Peterdi, J., Manabe, K., et al. (2003). Macula densa cell signaling involves ATP release through a maxi anion channel. Proc. Natl. Acad. Sci. U.S.A. 100, 4322-4327. doi: 10.1073/pnas. 0736323100

Ben-Ari, Y., Khalilov, I., Kahle, K. T., and Cherubini, E. (2012). The GABA excitatory/inhibitory shift in brain maturation and neurological disorders. Neuroscientist 18, 467-486. doi: 10.1177/1073858412438697

Betelli, C., MacDermott, A. B., and Bardoni, R. (2015). Transient, activity dependent inhibition of transmitter release from low threshold afferents mediated by GABAA receptors in spinal cord lamina III/IV. Mol. Pain 11:64. doi: 10.1186/s12990-015-0067-5 of them, like $\mathrm{GABA}_{\mathrm{A}}$ receptors or Ano1, while the importance of others such as tweety homologs or CICA has not been explored although they are detectable in DRGs. Altogether, $\mathrm{Cl}^{-}$ions are emerging as relevant components of nociceptor function and should no longer be underrated as important players in acute pain processing and the pathogenesis of chronic pain disorders.

\section{AUTHOR CONTRIBUTIONS}

All authors listed have made a substantial contribution to writing the manuscript, revised it and approved it for publication. BW designed the figures.

\section{FUNDING}

The authors received funding from the Austrian Science Fund (FWF): DK-SPIN W1206-06, P25345, and P28611 to MK, and P30809 to KK; the Austrian Research Promotion Agency (FFG): 6087105 to $\mathrm{MK}$; and the European Commission under FP7: GAnr. 602133 to MK.

Bharill, S., Fu, Z., Palty, R., and Isacoff, E. Y. (2014). Stoichiometry and specific assembly of Best ion channels. Proc. Natl. Acad. Sci. U.S.A. 111, 6491-6496. doi: 10.1073/pnas.1400248111

Bhat, R., Axtell, R., Mitra, A., Miranda, M., Lock, C., Tsien, R. W., et al. (2010). Inhibitory role for GABA in autoimmune inflammation. Proc. Natl. Acad. Sci. U.S.A. 107, 2580-2585. doi: 10.1073/pnas.0915 139107

Bhisitkul, R. B., Kocsis, J. D., Gordon, T. R., and Waxman, S. G. (1990). Trophic influence of the distal nerve segment on GABAA receptor expression in axotomized adult sensory neurons. Exp. Neurol. 109, 273-278. doi: 10.1016/ s0014-4886(05)80017-2

Bhisitkul, R. B., Villa, J. E., and Kocsis, J. D. (1987). Axonal GABA receptors are selectively present on normal and regenerated sensory fibers in rat peripheral nerve. Exp. Brain Res. 66, 659-663. doi: 10.1007/bf00270698

Bormann, J. (2000). The ABC of GABA receptors. Trends Pharmacol. Sci. 21, 16-19. doi: 10.1016/s0165-6147(99)01413-3

Boudes, M., Sar, C., Menigoz, A., Hilaire, C., Pequignot, M. O., Kozlenkov, A., et al. (2009). Best1 is a gene regulated by nerve injury and required for Ca2+activated Cl- current expression in axotomized sensory neurons. J. Neurosci. 29, 10063-10071. doi: 10.1523/JNEUROSCI.1312-09.2009

Bourinet, E., and Zamponi, G. W. (2005). Voltage gated calcium channels as targets for analgesics. Curr. Top. Med. Chem 5, 539-546. doi: 10.2174/ 1568026054367610

Bravo-Hernandez, M., Corleto, J. A., Barragan-Iglesias, P., Gonzalez-Ramirez, R., Pineda-Farias, J. B., Felix, R., et al. (2016). The alpha5 subunit containing GABAA receptors contribute to chronic pain. Pain 157, 613-626. doi: 10.1097/ j.pain.0000000000000410

Bravo-Hernandez, M., Feria-Morales, L. A., Torres-Lopez, J. E., Cervantes-Duran, C., Delgado-Lezama, R., Granados-Soto, V., et al. (2014). Evidence for the participation of peripheral alpha5 subunit-containing GABAA receptors in GABAA agonists-induced nociception in rats. Eur. J. Pharmacol. 734, 91-97. doi: 10.1016/j.ejphar.2014.03.051

Budai, D., and Fields, H. L. (1998). Endogenous opioid peptides acting at muopioid receptors in the dorsal horn contribute to midbrain modulation of spinal nociceptive neurons. J. Neurophysiol. 79, 677-687. doi: 10.1152/jn.1998.79.2. 677

Burnstock, G. (2013). Purinergic mechanisms and pain-an update. Eur. J. Pharmacol. 716, 24-40. doi: 10.1016/j.ejphar.2013.01.078

Camprubi-Robles, M., Mair, N., Andratsch, M., Benetti, C., Beroukas, D., Rukwied, R., et al. (2013). Sphingosine-1-phosphate-induced nociceptor excitation and 
ongoing pain behavior in mice and humans is largely mediated by S1P3 receptor. J. Neurosci. 33, 2582-2592. doi: 10.1523/JNEUROSCI.4479-12.2013

Caputo, A., Caci, E., Ferrera, L., Pedemonte, N., Barsanti, C., Sondo, E., et al. (2008). TMEM16A, a membrane protein associated with calcium-dependent chloride channel activity. Science 322, 590-594. doi: 10.1126/science.1163518

Carlton, S. M., Zhou, S., and Coggeshall, R. E. (1999). Peripheral GABA(A) receptors: evidence for peripheral primary afferent depolarization. Neuroscience 93, 713-722. doi: 10.1016/s0306-4522(99)00101-3

Chakrabarti, S., Pattison, L. A., Singhal, K., Hockley, J. R. F., Callejo, G., and Smith, E. S. J. (2018). Acute inflammation sensitizes knee-innervating sensory neurons and decreases mouse digging behavior in a TRPV1-dependent manner. Neuropharmacology 143, 49-62. doi: 10.1016/j.neuropharm.2018.09.014

Chen, J. T., Guo, D., Campanelli, D., Frattini, F., Mayer, F., Zhou, L., et al. (2014). Presynaptic GABAergic inhibition regulated by BDNF contributes to neuropathic pain induction. Nat. Commun. 5:5331. doi: 10.1038/ncomms6331

Chen, Q. Y., Tan, C. Y., Wang, Y., Ma, K. T., Li, L., and Si, J. Q. (2019). Mechanism of persistent hyperalgesia in neuropathic pain caused by chronic constriction injury. Neural Regen. Res. 14, 1091-1098. doi: 10.4103/1673-5374.250631

Cho, H., Yang, Y. D., Lee, J., Lee, B., Kim, T., Jang, Y., et al. (2012). The calciumactivated chloride channel anoctamin 1 acts as a heat sensor in nociceptive neurons. Nat. Neurosci. 15, 1015-1021. doi: 10.1038/nn.3111

Cordero-Erausquin, M., Coull, J. A. M., Boudreau, D., Rolland, M., and De Koninck, Y. (2005). Differential maturation of GABA action and anion reversal potential in spinal lamina I neurons: impact of chloride extrusion capacity. J. Neurosci. 25, 9613-9623. doi: 10.1523/jneurosci.1488-05.2005

Coull, J. A. M., Boudreau, D., Bachand, K., Prescott, S. A., Nault, F., Sík, A., et al. (2003). Trans-synaptic shift in anion gradient in spinal lamina I neurons as a mechanism of neuropathic pain. Nature 424, 938-942. doi: 10.1038/ nature 01868

De Groat, W. C., Lalley, P. M., and Saum, W. R. (1972). Depolarization of dorsal root ganglia in the cat by GABA and related amino acids: antagonism by picrotoxin and bicuculline. Brain Res. 44, 273-277. doi: 10.1016/0006-8993(72) 90383-6

De la Luz-Cuellar, Y. E., Rodriguez-Palma, E. J., Franco-Enzastiga, U., SalinasAbarca, A. B., Delgado-Lezama, R., and Granados-Soto, V. (2019). Blockade of spinal alpha5-GABAA receptors differentially reduces reserpine-induced fibromyalgia-type pain in female rats. Eur. J. Pharmacol. 858:172443. doi: 10. 1016/j.ejphar.2019.172443

Deba, F., and Bessac, B. F. (2015). Anoctamin-1 Cl- channels in nociception: activation by an $\mathrm{N}$-aroylaminothiazole and capsaicin and inhibition by T16A[inh]-A01. Mol. Pain 11:12990. doi: 10.1186/s12990-015-0061-y

Desarmenien, M., Feltz, P., and Headley, P. M. (1979). The depolarizing responses to GABA in rat sensory ganglia in vivo and in vitro. A study of the role of glial uptake. J. Physiol. 75, 661-665.

Desarmenien, M., Feltz, P., and Headley, P. M. (1980). Does glial uptake affect GABA responses? AN intracellular study on rat dorsal root ganglion neurones in vitro. J. Physiol. 307, 163-182. doi: 10.1113/jphysiol.1980. sp013429

Desarmenien, M., Santangelo, F., Linck, G., Headley, P. M., and Feltz, P. (1981). Physiological study of amino acid uptake and receptor desensitization: the GABA system in dorsal root ganglia. Adv. Biochem. Psychopharmacol. 29, 309-319.

Di Lio, A., Benke, D., Besson, M., Desmeules, J., Daali, Y., Wang, Z. J., et al. (2011). HZ166, a novel GABAA receptor subtype-selective benzodiazepine site ligand, is antihyperalgesic in mouse models of inflammatory and neuropathic pain. Neuropharmacology 60, 626-632. doi: 10.1016/j.neuropharm.2010. 11.026

Ding, J., and Delpire, E. (2014). Deletion of KCC3 in parvalbumin neurons leads to locomotor deficit in a conditional mouse model of peripheral neuropathy associated with agenesis of the corpus callosum. Behav. Brain Res. 274, 128-136. doi: 10.1016/j.bbr.2014.08.005

Doyon, N., Prescott, S. A., Castonguay, A., Godin, A. G., Kröger, H., and De Koninck, Y. (2011). Efficacy of synaptic inhibition depends on multiple, dynamically interacting mechanisms implicated in chloride homeostasis. PLoS Comput. Biol. 7:e1002149. doi: 10.1371/journal.pcbi.1002149

Doyon, N., Vinay, L., Prescott, S. A., Koninck, Y. D., and De Koninck, Y. (2016). Chloride regulation: a dynamic equilibrium crucial for synaptic inhibition. Neuron 89, 1157-1172. doi: 10.1016/j.neuron.2016.02.030
Du, X., Hao, H., Yang, Y., Huang, S., Wang, C., Gigout, S., et al. (2017). Local GABAergic signaling within sensory ganglia controls peripheral nociceptive transmission. J. Clin. Invest. 127, 1741-1756. doi: 10.1172/JCI86812

Dutertre, S., Becker, C. M., and Betz, H. (2012). Inhibitory glycine receptors: an update. J. Biol. Chem. 287, 40216-40223. doi: 10.1074/jbc.R112.408229

Ebbinghaus, M., Gajda, M., Holtzman, M. J., Schulz, S., and Schaible, H.-G. (2014). Does chloride channel accessory 3 have a role in arthritis pain? A study on murine antigen-induced arthritis. Neurosci. Lett. 576, 40-44. doi: 10.1016/j. neulet.2014.05.051

Enna, S. J., and McCarson, K. E. (2006). The role of GABA in the mediation and perception of pain. Adv. Pharmacol. 54, 1-27. doi: 10.1016/s1054-3589(06) 54001-3

Ertongur-Fauth, T., Hochheimer, A., Buescher, J. M., Rapprich, S., and Krohn, M. (2014). A novelTMEM16Asplice variant lacking the dimerization domain contributes to calcium-activated chloride secretion in human sweat gland epithelial cells. Exp. Dermatol. 23, 825-831. doi: 10.1111/exd.12543

Evans, S. R., Thoreson, W. B., and Beck, C. L. (2004). Molecular and functional analyses of two new calcium-activated chloride channel family members from mouse eye and intestine. J. Biol. Chem. 279, 41792-41800. doi: 10.1074/jbc. $\mathrm{m} 408354200$

Ferrera, L., Caputo, A., Ubby, I., Bussani, E., Zegarra-Moran, O., Ravazzolo, R., et al. (2009). Regulation of TMEM16A chloride channel properties by alternative splicing. J. Biol. Chem. 284, 33360-33368. doi: 10.1074/jbc.M109. 046607

Fischmeister, R., and Hartzell, H. C. (2005). Volume sensitivity of the bestrophin family of chloride channels. J. Physiol. 562, 477-491. doi: 10.1113/jphysiol.2004. 075622

Flegel, C., Schöbel, N., Altmüller, J., Becker, C., Tannapfel, A., Hatt, H., et al. (2015). RNA-Seq analysis of human trigeminal and dorsal root ganglia with a focus on chemoreceptors. PLoS One 10:e0128951. doi: 10.1371/journal.pone. 0128951

Francois, A., Low, S. A., Sypek, E. I., Christensen, A. J., Sotoudeh, C., Beier, K. T., et al. (2017). A brainstem-spinal cord inhibitory circuit for mechanical pain modulation by GABA and enkephalins. Neuron 93:82. doi: 10.1016/j.neuron. 2017.01.008

Funk, K., Woitecki, A., Franjic-Würtz, C., Gensch, T., Möhrlen, F., and Frings, S. (2008). Modulation of chloride homeostasis by inflammatory mediators in dorsal root ganglion neurons. Mol. Pain 4, 1-12. doi: 10.1186/1744-8069-4-32

Furuyama, T., Sato, M., Sato, K., Araki, T., Inagaki, S., Takagi, H., et al. (1992). Co-expression of glycine receptor beta subunit and GABAA receptor gamma subunit mRNA in the rat dorsal root ganglion cells. Brain Res. Mol. Brain Res. 12, 335-338. doi: 10.1016/0169-328x(92)90136-y

Galaz, P., Barra, R., Figueroa, H., and Mariqueo, T. (2015). Advances in the pharmacology of lGICs auxiliary subunits. Pharmacol. Res. 101, 65-73. doi: 10.1016/j.phrs.2015.07.026

Gallagher, J. P., Nakamura, J., and Shinnick-Gallagher, P. (1983a). Effects of glial uptake and desensitization on the activity of gamma-aminobutyric acid (GABA) and its analogs at the cat dorsal root ganglion. J. Pharmacol. Exp. Ther. 226, 876-884.

Gallagher, J. P., Nakamura, J., and Shinnick-Gallagher, P. (1983b). The effects of temperature, $\mathrm{pH}$ and $\mathrm{Cl}$-pump inhibitors on GABA responses recorded from cat dorsal root ganglia. Brain Res. 267, 249-259. doi: 10.1016/0006-8993(83) 90877-6

Gamba, G. (2005). Molecular physiology and pathophysiology of electroneutral cation-chloride cotransporters. Physiol. Rev. 85, 423-493. doi: 10.1152/physrev. 00011.2004

Gandhi, R., Elble, R. C., Gruber, A. D., Schreur, K. D., Ji, H. L., Fuller, C. M., et al. (1998). Molecular and functional characterization of a calcium-sensitive chloride channel from mouse lung. J. Biol. Chem. 273, 32096-32101. doi: 10.1074/jbc.273.48.32096

García, G., Martínez-Rojas, V. A., Rocha-González, H. I., Granados-Soto, V., and Murbartián, J. (2014). Evidence for the participation of Ca2+-activated chloride channels in formalin-induced acute and chronic nociception. Brain Res. 1579, 35-44. doi: 10.1016/j.brainres.2014.07.011

Gibson, A., Lewis, A. P., Affleck, K., Aitken, A. J., Meldrum, E., and Thompson, N. (2005). hCLCA1 and mCLCA3 are secreted non-integral membrane proteins and therefore are not ion channels. J. Biol. Chem. 280, 27205-27212. doi: $10.1074 /$ jbc.m504654200 
Gilbert, D., Franjic-Würtz, C., Funk, K., Gensch, T., Frings, S., and Möhrlen, F. (2007). Differential maturation of chloride homeostasis in primary afferent neurons of the somatosensory system. Intern. J. Dev. Neurosci. 25, 479-489. doi: 10.1016/j.ijdevneu.2007.08.001

Golubinskaya, V., Vontell, R., Supramaniam, V., Gustafsson, H., Mallard, C., and Nilsson, H. (2019). Bestrophin-3 expression in a subpopulation of astrocytes in the neonatal brain after hypoxic-ischemic injury. Front. Physiol. 10:23. doi: $10.3389 /$ fphys.2019.00023

Grubb, S., Poulsen, K. A., Juul, C. A., Kyed, T., Klausen, T. K., Larsen, E. H., et al. (2013). TMEM16F (Anoctamin 6), an anion channel of delayed Ca2+activation. J. Gen. Physiol. 141, 585-600. doi: 10.1085/jgp.201210861

Gruber, A. D., Elble, R. C., Ji, H.-L., Schreur, K. D., Fuller, C. M., and Pauli, B. U. (1998). Genomic cloning, molecular characterization, and functional analysis of human clca1, the first human member of the family of Ca2+-activated Cl-channel proteins. Genomics 54, 200-214. doi: 10.1006/geno.1998.5562

Gruber, A. D., Schreur, K. D., Ji, H.-L., Fuller, C. M., and Pauli, B. U. (1999). Molecular cloning and transmembrane structure of hCLCA2 from human lung, trachea, and mammary gland. Am. J. Physiol. Cell Physiol. 276, C1261-C1270.

Guan, B. C., Li, Z. W., and Zhou, X. P. (1994). Modulatory effects of substance P on the membrane responses mediated by GABAA and GABAB receptors in DRG neurons. Sheng Li Xue Bao 46, 441-450.

Gulledge, A. T., and Stuart, G. J. (2003). Excitatory actions of GABA in the cortex. Neuron 37, 299-309. doi: 10.1016/s0896-6273(02)01146-7

Guo, Y., Su, M., Su, M., McNutt, M. A., and Gu, J. (2009). Expression and distribution of cystic fibrosis transmembrane conductance regulator in neurons of the spinal cord. J. Neurosci. Res. 87, 3611-3619. doi: 10.1002/jnr. 22154

Guzman, R. E., Miranda-Laferte, E., Franzen, A., and Fahlke, C. (2015). Neuronal ClC-3 splice variants differ in subcellular localizations, but mediate identical transport functions. J. Biol. Chem. 290, 25851-25862. doi: 10.1074/jbc.M115. 668186

Han, Y.-E., Kwon, J., Won, J., An, H., Jang, M. W., Woo, J., et al. (2019). Tweetyhomolog (Ttyh) family encodes the pore-forming subunits of the swellingdependent volume-regulated anion channel (VRACswell) in the Brain. Exp. Neurobiol. 28:183. doi: 10.5607/en.2019.28.2.183

Hartzell, H. C., Qu, Z., Yu, K., Xiao, Q., and Chien, L.-T. (2008). Molecular physiology of bestrophins: multifunctional membrane proteins linked to best disease and other retinopathies. Physiol. Rev. 88, 639-672. doi: 10.1152/physrev. 00022.2007

Harvey, R. J., Depner, U. B., Wassle, H., Ahmadi, S., Heindl, C., Reinold, H., et al. (2004). GlyR alpha3: an essential target for spinal PGE2-mediated inflammatory pain sensitization. Science 304, 884-887. doi: 10.1126/science.1094925

Heinricher, M. M., Tavares, I., Leith, J. L., and Lumb, B. M. (2009). Descending control of nociception: Specificity, recruitment and plasticity. Brain Res. Rev. 60, 214-225. doi: 10.1016/j.brainresrev.2008.12.009

Hu, H. Z., and Li, Z. W. (1997). Modulation by adenosine of GABA-activated current in rat dorsal root ganglion neurons. J. Physiol. 501(Pt 1), 67-75. doi: 10.1111/j.1469-7793.1997.067bo.x

Huang, P., Liu, J., Di, A., Robinson, N. C., Musch, M. W., Kaetzel, M. A., et al. (2001). Regulation of human CLC-3 channels by multifunctional Ca2+/calmodulin-dependent protein kinase. J. Biol. Chem. 276, 20093-20100. doi: 10.1074/jbc.m009376200

Hwang, T. C., and Kirk, K. L. (2013). The CFTR ion channel: gating, regulation, and anion permeation. Cold Spring Harb. Perspect. Med. 3:a009498. doi: 10.1101/ cshperspect.a009498

Imhof, A.-K., Glück, L., Gajda, M., Bräuer, R., Schaible, H.-G., and Schulz, S. (2011). Potent anti-inflammatory and antinociceptive activity of the endothelin receptor antagonist bosentan in monoarthritic mice. Arthrit. Res. Ther. 13:R97. doi: $10.1186 / \operatorname{ar} 3372$

Jahr, C. E., and Jessell, T. M. (1983). ATP excites a subpopulation of rat dorsal horn neurones. Nature 304, 730-733. doi: 10.1038/304730a0

Jang, I. J., Davies, A. J., Akimoto, N., Back, S. K., Lee, P. R., Na, H. S., et al. (2017). Acute inflammation reveals GABAA receptor-mediated nociception in mouse dorsal root ganglion neurons via PGE2 receptor 4 signaling. Physiol. Rep. 5:e13178. doi: 10.14814/phy2.13178

Jennings, E. M., Okine, B. N., Roche, M., and Finn, D. P. (2014). Stress-induced hyperalgesia. Prog. Neurobiol. 121, 1-18. doi: 10.1016/j.pneurobio.2014. 06.003
Jentsch, T. J., Lutter, D., Planells-Cases, R., Ullrich, F., and Voss, F. K. (2016). VRAC: molecular identification as LRRC8 heteromers with differential functions. Pflugers. Arch. 468, 385-393. doi: 10.1007/s00424-015-1766-5

Jentsch, T. J., Poet, M., Fuhrmann, J. C., and Zdebik, A. A. (2005). Physiological functions of CLC Cl- channels gleaned from human genetic disease and mouse models. Annu. Rev. Physiol. 67, 779-807. doi: 10.1146/annurev.physiol.67. 032003.153245

Jentsch, T. J., and Pusch, M. (2018). CLC chloride channels and transporters: structure, function, physiology, and disease. Physiol. Rev. 98, 1493-1590. doi: 10.1152/physrev.00047.2017

Jentsch, T. J., Steinmeyer, K., and Schwarz, G. (1990). Primary structure of torpedo marmorata chloride channel isolated by expression cloning in Xenopus oocytes. Nature 348, 510-514. doi: 10.1038/348510a0

Jin, X., Shah, S., Du, X., Zhang, H., and Gamper, N. (2016). Activation of Ca(2+) activated $\mathrm{Cl}(-)$ channel ANO1 by localized $\mathrm{Ca}(2+)$ signals. J. Physiol. 594, 19-30. doi: 10.1113/jphysiol.2014.275107

Jin, X., Shah, S., Liu, Y., Zhang, H., Lees, M., Fu, Z., et al. (2013). Activation of the Cl- channel ANO1 by localized calcium signals in nociceptive sensory neurons requires coupling with the IP3 receptor. Sci. Signal. 6:ra73. doi: 10. 1126/scisignal.2004184

Kaila, K., Price, T. J., Payne, J. A., Puskarjov, M., and Voipio, J. (2014). Cationchloride cotransporters in neuronal development, plasticity and disease. Nat. Rev. Neurosci. 15, 637-654. doi: 10.1038/nrn3819

Kalpachidou, T., Spiecker, L., Kress, M., and Quarta, S. (2019). Rho GTPases in the physiology and pathophysiology of peripheral sensory neurons. Cells 8:591. doi: 10.3390/cells8060591

Kanai, N., Lu, R., Satriano, J. A., Bao, Y., Wolkoff, A. W., and Schuster, V. L. (1995). Identification and characterization of a prostaglandin transporter. Science 268, 866-869. doi: 10.1126/science.7754369

Kanaka, C., Ohno, K., Okabe, A., Kuriyama, K., Itoh, T., Fukuda, A., et al. (2001). The differential expression patterns of messenger RNAs encoding $\mathrm{K}-\mathrm{Cl}$ cotransporters $(\mathrm{KCC} 1,2)$ and $\mathrm{Na}-\mathrm{K}-2 \mathrm{Cl}$ cotransporter $(\mathrm{NKCC} 1)$ in the rat nervous system. Neuroscience 104, 933-946. doi: 10.1016/s0306-4522(01) 00149-x

Kane Dickson, V., Pedi, L., and Long, S. B. (2014). Structure and insights into the function of a Ca2+-activated Cl- channel. Nature 516, 213-218. doi: 10.1038/ nature 13913

Kanno, T., and Nishizaki, T. (2011). CFTR mediates noradrenaline-induced ATP efflux from DRG neurons. Mol. Pain 7:72. doi: 10.1186/1744-8069-7-72

Kanno, T., Yaguchi, T., and Nishizaki, T. (2010). Noradrenaline stimulates ATP release from DRG neurons by targeting beta(3) adrenoceptors as a factor of neuropathic pain. J. Cell. Physiol. 224, 345-351. doi: 10.1002/jcp.22114

Kawasaki, M., Suzuki, M., Uchida, S., Sasaki, S., and Marumo, F. (1995). Stable and functional expression of the CIC-3 chloride channel in somatic cell lines. Neuron 14, 1285-1291. doi: 10.1016/0896-6273(95)90275-9

Knabl, J., Witschi, R., Hosl, K., Reinold, H., Zeilhofer, U. B., Ahmadi, S., et al. (2008). Reversal of pathological pain through specific spinal GABAA receptor subtypes. Nature 451, 330-334. doi: 10.1038/nature06493

Kullmann, D. M., Ruiz, A., Rusakov, D. M., Scott, R., Semyanov, A., and Walker, M. C. (2005). Presynaptic, extrasynaptic and axonal GABAA receptors in the CNS: where and why? Prog. Biophys. Mol. Biol. 87, 33-46. doi: 10.1016/j. pbiomolbio.2004.06.003

Kuner, T., and Augustine, G. J. (2000). A genetically encoded ratiometric indicator for chloride: capturing chloride transients in cultured hippocampal neurons. Neuron 27, 447-459. doi: 10.1016/s0896-6273(00)00056-8

Kuo, Y.-H., Abdullaev, I. F., Hyzinski-García, M. C., and Mongin, A. A. (2014) Effects of alternative splicing on the function of bestrophin-1 calcium-activated chloride channels. Biochem. J. 458, 575-583. doi: 10.1042/bj20121546

Labrakakis, C., Tong, C. K., Weissman, T., Torsney, C., and MacDermott, A. B. (2003). Localization and function of ATP and GABAA receptors expressed by nociceptors and other postnatal sensory neurons in rat. J. Physiol. 549(Pt 1), 131-142. doi: 10.1113/jphysiol.2002.031963

Le, S. C., Jia, Z., Chen, J., and Yang, H. (2019). Molecular basis of PIP2-dependent regulation of the Ca2+-activated chloride channel TMEM16A. Nat. Commun. 10:3769. doi: 10.1038/s41467-019-11784-8

Lee, B., Cho, H., Jung, J., Yang, Y. D., Yang, D.-J., and Oh, U. (2014). Anoctamin 1 contributes to inflammatory and nerve-injury induced hypersensitivity. Mol. Pain 10, 1710-1745. 
Lee, K. Y., Charbonnet, M., and Gold, M. S. (2012). Upregulation of high-affinity GABA(A) receptors in cultured rat dorsal root ganglion neurons. Neuroscience 208, 133-142. doi: 10.1016/j.neuroscience.2012.01.050

Lee, S., Yoon, B. E., Berglund, K., Oh, S. J., Park, H., Shin, H. S., et al. (2010). Channel-mediated tonic GABA release from Glia. Science 330, 790-796. doi: $10.1126 /$ science. 1184334

Li, C., Li, J. N., Kays, J., Guerrero, M., and Nicol, G. D. (2015). Sphingosine 1phosphate enhances the excitability of rat sensory neurons through activation of sphingosine 1-phosphate receptors 1 and/or 3. J. Neuroinflamm. 12:70.

Li, L., Zhao, L., Wang, Y., Ma, K. T., Shi, W. Y., Wang, Y. Z., et al. (2015). PKCvarepsilon mediates substance $P$ inhibition of GABAA receptors-mediated current in rat dorsal root ganglion. J. Huazhong Univ. Sci. Technolog. Med. Sci. 35, 1-9. doi: 10.1007/s11596-015-1380-y

Li, J., Blankenship, M. L., and Baccei, M. L. (2013). Deficits in glycinergic inhibition within adult spinal nociceptive circuits after neonatal tissue damage. Pain 154, 1129-1139. doi: 10.1016/j.pain.2013.03.030

Li, L., Chen, S. R., Chen, H., Wen, L., Hittelman, W. N., Xie, J. D., et al. (2016). Chloride homeostasis critically regulates synaptic NMDA receptor activity in neuropathic pain. Cell Rep. 15, 1376-1383. doi: 10.1016/j.celrep.2016.04.039

Li, S., An, J., Sun, C. K., and Li, Z. W. (2004). Inhibitory effect of caffeine on GABAactivated current in acutely isolated rat dorsal root ganglion neurons. Sheng $L i$ Xue Bao 56, 384-388.

Lidierth, M. (2006). Local and diffuse mechanisms of primary afferent depolarization and presynaptic inhibition in the rat spinal cord. J. Physiol. 576(Pt 1), 309-327. doi: 10.1113/jphysiol.2006.110577

Lin, H., Jun, I., Woo, J. H., Lee, M. G., Kim, S. J., and Nam, J. H. (2019). Temperature-dependent increase in the calcium sensitivity and acceleration of activation of ANO6 chloride channel variants. Sci. Rep. 9:6706. doi: 10.1038/ s41598-019-43162-1

Liu, B., Linley, J. E., Du, X., Zhang, X., Ooi, L., Zhang, H., et al. (2010). The acute nociceptive signals induced by bradykinin in rat sensory neurons are mediated by inhibition of M-type $\mathrm{K}+$ channels and activation of $\mathrm{Ca} 2+$-activated $\mathrm{Cl}-$ channels. J. Clin. Invest. 120, 1240-1252. doi: 10.1172/JCI41084

Liu, G. J., Kalous, A., Werry, E. L., and Bennett, M. R. (2006). Purine release from spinal cord microglia after elevation of calcium by glutamate. Mol. Pharmacol. 70, 851-859. doi: 10.1124/mol.105.021436

Liu, S., Feng, J., Luo, J., Yang, P., Brett, T. J., and Hu, H. (2016). Eact, a small molecule activator of TMEM16A, activates TRPV1 and elicits pain- and itchrelated behaviours. Br. J. Pharmacol. 173, 1208-1218. doi: 10.1111/bph.13420

Liu, Y., Zhang, H., Men, H., Du, Y., Xiao, Z., Zhang, F., et al. (2019). Volumeregulated $\mathrm{Cl}(-)$ current: contributions of distinct $\mathrm{Cl}(-)$ channels and localized $\mathrm{Ca}(2+)$ signals. Am. J. Physiol. Cell Physiol. 317, C466-C480. doi: 10.1152/ ajpcell.00507.2018

Loewen, M. E., and Forsyth, G. W. (2005). Structure and function of CLCA proteins. Physiol. Rev. 85, 1061-1092. doi: 10.1152/physrev.00016.2004

Lucas, O., Hilaire, C., Delpire, E., and Scamps, F. (2012). KCC3-dependent chloride extrusion in adult sensory neurons. Mol. Cell. Neurosci. 50, 211-220. doi: 10. 1016/j.mcn.2012.05.005

Lynch, J. W. (2009). Native glycine receptor subtypes and their physiological roles. Neuropharmacology 56, 303-309. doi: 10.1016/j.neuropharm.2008. 07.034

Lynch, J. W., Zhang, Y., Talwar, S., and Estrada-Mondragon, A. (2017). Glycine receptor drug discovery. Adv. Pharmacol. 79, 225-253. doi: 10.1016/bs.apha. 2017.01.003

Ma, W., Saunders, P. A., Somogyi, R., Poulter, M. O., and Barker, J. L. (1993). Ontogeny of GABAA receptor subunit mRNAs in rat spinal cord and dorsal root ganglia. J. Comp. Neurol. 338, 337-359. doi: 10.1002/cne.903380303

Maddox, F. N., Valeyev, A. Y., Poth, K., Holohean, A. M., Wood, P. M., Davidoff, R. A., et al. (2004). GABAA receptor subunit mRNA expression in cultured embryonic and adult human dorsal root ganglion neurons. Brain Res. Dev. Brain Res. 149, 143-151. doi: 10.1016/j.devbrainres.2004.01.001

Mair, N., Benetti, C., Andratsch, M., Leitner, M. G., Constantin, C. E., CamprubiRobles, M., et al. (2011). Genetic evidence for involvement of neuronally expressed S1P(1) receptor in nociceptor sensitization and inflammatory pain. PLoS One 6:e17268. doi: 10.1371/journal.pone.0017268

Marcorelles, P., Friocourt, G., Uguen, A., Lede, F., Ferec, C., and Laquerriere, A. (2014). Cystic fibrosis transmembrane conductance regulator protein (CFTR) expression in the developing human brain: comparative immunohistochemical study between patients with normal and mutated CFTR. J. Histochem. Cytochem. 62, 791-801. doi: 10.1369/0022155414546190

Mazzone, A., Bernard, C. E., Strege, P. R., Beyder, A., Galietta, L. J. V., Pasricha, P. J., et al. (2011). Altered expression of ano1 variants in human diabetic gastroparesis. J. Biol. Chem. 286, 13393-13403. doi: 10.1074/jbc.M110.196089

Modol, L., Cobianchi, S., and Navarro, X. (2014). Prevention of NKCC1 phosphorylation avoids downregulation of KCC2 in central sensory pathways and reduces neuropathic pain after peripheral nerve injury. Pain 155, 15771590. doi: 10.1016/j.pain.2014.05.004

Morales-Aza, B. M., Chillingworth, N. L., Payne, J. A., and Donaldson, L. F. (2004). Inflammation alters cation chloride cotransporter expression in sensory neurons. Neurobiol. Dis. 17, 62-69. doi: 10.1016/j.nbd.2004.05.010

Mulberg, A. E., Resta, L. P., Wiedner, E. B., Altschuler, S. M., Jefferson, D. M., and Broussard, D. L. (1995). Expression and localization of the cystic fibrosis transmembrane conductance regulator mRNA and its protein in rat brain. J. Clin. Invest. 96, 646-652. doi: 10.1172/jci118080

Mulberg, A. E., Weyler, R. T., Altschuler, S. M., and Hyde, T. M. (1998). Cystic fibrosis transmembrane conductance regulator expression in human hypothalamus. Neuroreport 9, 141-144. doi: 10.1097/00001756-19980105000028

Mulberg, A. E., Wiedner, E. B., Bao, X., Marshall, J., Jefferson, D. M., and Altschuler, S. M. (1994). Cystic fibrosis transmembrane conductance regulator protein expression in brain. Neuroreport 5, 1684-1688.

Mundhenk, L., Alfalah, M., Elble, R. C., Pauli, B. U., Naim, H. Y., and Gruber, A. D. (2006). Both cleavage products of the mCLCA3 protein are secreted soluble proteins. J. Biol. Chem. 281, 30072-30080. doi: 10.1074/jbc.m606 489200

Naik, A. K., Latham, J. R., Obradovic, A., and Jevtovic-Todorovic, V. (2012). Dorsal root ganglion application of muscimol prevents hyperalgesia and stimulates myelin protein expression after sciatic nerve injury in rats. Anesth. Analg. 114, 674-682. doi: 10.1213/ANE.0b013e31823fad7e

Naik, A. K., Pathirathna, S., and Jevtovic-Todorovic, V. (2008). GABAA receptor modulation in dorsal root ganglia in vivo affects chronic pain after nerve injury. Neuroscience 154, 1539-1553. doi: 10.1016/j.neuroscience.2008. 04.061

Niu, N., Zhang, J., Guo, Y., Yang, C., and Gu, J. (2009). Cystic fibrosis transmembrane conductance regulator expression in human spinal and sympathetic ganglia. Lab. Invest. 89, 636-644. doi: 10.1038/labinvest.2009.28

Obata, K., Yamanaka, H., Fukuoka, T., Yi, D., Tokunaga, A., Hashimoto, N., et al. (2003). Contribution of injured and uninjured dorsal root ganglion neurons to pain behavior and the changes in gene expression following chronic constriction injury of the sciatic nerve in rats. Pain 101, 65-77. doi: 10.1016/ s0304-3959(02)00296-8

Obradovic, A. L., Scarpa, J., Osuru, H. P., Weaver, J. L., Park, J. Y., Pathirathna, S., et al. (2015). Silencing the alpha2 subunit of gamma-aminobutyric acid type A receptors in rat dorsal root ganglia reveals its major role in antinociception posttraumatic nerve injury. Anesthesiology 123, 654-667. doi: 10.1097/ALN. 0000000000000767

O'Driscoll, K. E., Hatton, W. J., Burkin, H. R., Leblanc, M., and Britton, F. C. (2008). Expression, localization, and functional properties of Bestrophin 3 channel isolated from mouse heart. Am. J. Physiol. Cell Physiol. 295, C1610-C1624. doi: 10.1152/ajpcell.00461.2008

O’Driscoll, K. E., Leblanc, N., Hatton, W. J., and Britton, F. C. (2009). Functional properties of murine bestrophin 1 channel. Biochem. Biophys. Res. Commun. 384, 476-481. doi: 10.1016/j.bbrc.2009.05.008

Oh, U., and Jung, J. (2016). Cellular functions of TMEM16/anoctamin. Pflugers. Arch. 468, 443-453. doi: 10.1007/s00424-016-1790-0

Okada, T., Akita, T., Sato-Numata, K., Islam, M. R., and Okada, Y. (2014). A newly cloned ClC-3 isoform, ClC-3d, as well as ClC-3a mediates Cd-sensitive outwardly rectifying anion currents. Cell Physiol. Biochem. 33, 539-556. doi: $10.1159 / 000358633$

Olsen, R. W. (2002). "Chapter 12: GABA," in Neuropsychopharmacology - 5th Generation of Progress, eds K. L. Davis, D. Charney, J. T. Coyle, and C. Nemeroff (Philadelphia, PA: Lippincott, Williams \& Wilkins).

Oyelese, A. A., and Kocsis, J. D. (1996). GABAA-receptor-mediated conductance and action potential waveform in cutaneous and muscle afferent neurons of the adult rat: differential expression and response to nerve injury. J. Neurophysiol. 76, 2383-2392. doi: 10.1152/jn.1996.76.4.2383 
Oyelese, A. A., Rizzo, M. A., Waxman, S. G., and Kocsis, J. D. (1997). Differential effects of NGF and BDNF on axotomy-induced changes in GABA(A)-receptormediated conductance and sodium currents in cutaneous afferent neurons. J. Neurophysiol. 78, 31-42. doi: 10.1152/jn.1997.78.1.31

Padjen, A. L., Mitsoglou, G. M., and Hassessian, H. (1989). Further evidence in support of taurine as a mediator of synaptic transmission in the frog spinal cord. Brain Res. 488, 288-296. doi: 10.1016/0006-8993(89)90720-8

Pang, R. P., Xie, M. X., Yang, J., Shen, K. F., Chen, X., Su, Y. X., et al. (2016). Downregulation of ClC-3 in dorsal root ganglia neurons contributes to mechanical hypersensitivity following peripheral nerve injury. Neuropharmacology 110(Pt A), 181-189. doi: 10.1016/j.neuropharm.2016.07. 023

Park, H., Han, K.-S., Oh, S.-J., Jo, S., Woo, J., Yoon, B.-E., et al. (2013). High glutamate permeability and distal localization of Bestl channel in CA1 hippocampal astrocyte. Mol. Brain 6:54. doi: 10.1186/1756-6606-6-54

Patel, A. C., Brett, T. J., and Holtzman, M. J. (2009). The role of CLCA proteins in inflammatory airway disease. Annu. Rev. Physiol. 71, 425-449. doi: 10.1146/ annurev.physiol.010908.163253

Paulino, C., Kalienkova, V., Lam, A. K. M., Neldner, Y., and Dutzler, R. (2017). Activation mechanism of the calcium-activated chloride channel TMEM16A revealed by cryo-EM. Nature 552, 421-425. doi: 10.1038/nature 24652

Payne, J. A., Rivera, C., Voipio, J., and Kaila, K. (2003). Cation-chloride cotransporters in neuronal communication, development and trauma. Trends Neurosci. 26, 199-206. doi: 10.1016/s0166-2236(03)00068-7

Pfeffer, C. K., Stein, V., Keating, D. J., Maier, H., Rinke, I., Rudhard, Y., et al. (2009). NKCC1-dependent GABAergic excitation drives synaptic network maturation during early hippocampal development. J. Neurosci. 29, 3419-3430. doi: 10. 1523/JNEUROSCI.1377-08.2009

Pieraut, S., Lucas, O., Sangari, S., Sar, C., Boudes, M., Bouffi, C., et al. (2011). An autocrine neuronal interleukin-6 loop mediates chloride accumulation and NKCC1 phosphorylation in axotomized sensory neurons. J. Neurosci. 31, 13516-13526. doi: 10.1523/JNEUROSCI.3382-11.2011

Pifferi, S., Dibattista, M., and Menini, A. (2009). TMEM16B induces chloride currents activated by calcium in mammalian cells. Pflügers Archiv. Eur. J. Physiol. 458, 1023-1038. doi: 10.1007/s00424-009-0684-9

Pineda-Farias, J. B., Barragan-Iglesias, P., Loeza-Alcocer, E., Torres-Lopez, J. E., Rocha-Gonzalez, H. I., and Perez-Severiano, F. (2015). Role of anoctamin-1 and bestrophin-1 in spinal nerve ligation-induced neuropathic pain in rats. Mol. Pain 11:12990. doi: 10.1186/s12990-015-0042-1

Poet, M., Kornak, U., Schweizer, M., Zdebik, A. A., Scheel, O., Hoelter, S., et al. (2006). Lysosomal storage disease upon disruption of the neuronal chloride transport protein ClC-6. Proc. Natl. Acad. Sci. U.S.A. 103, 13854-13859. doi: 10.1073/pnas.0606137103

Ponsioen, B., van Zeijl, L., Langeslag, M., Berryman, M., Littler, D., Jalink, K., et al. (2009). Spatiotemporal regulation of chloride intracellular channel protein CLIC4 by RhoA. Mol. Biol. Cell 20, 4664-4672. doi: 10.1091/mbc.E09-06-0529

Porreca, F., Ossipov, M. H., and Gebhart, G. F. (2002). Chronic pain and medullary descending facilitation. Trends Neurosci. 25, 319-325. doi: 10.1016/s01662236(02)02157-4

Prabhakar, E., and Lawson, S. N. (1995). The electrophysiological properties of rat primary afferent neurones with carbonic anhydrase activity. J. Physiol. 482, 609-622. doi: 10.1113/jphysiol.1995.sp020544

Prescott, S. A., Sejnowski, T. J., and Koninck, Y. De (2006). Reduction of anion reversal potential subverts the inhibitory control of firing rate in spinal lamina I neurons: towards a biophysical basis for neuropathic pain. Mol. Pain 2, 1-20.

Price, T. J., Cervero, F., Gold, M. S., Hammond, D. L., and Prescott, S. A. (2009). Chloride regulation in the pain pathway. Brain Res. Rev. 60, 149-170. doi: 10.1016/j.brainresrev.2008.12.015

Qi, Y., Mair, N., Kummer, K. K., Leitner, M. G., Camprubi-Robles, M., Langeslag, M., et al. (2018). Identification of chloride channels CLCN3 and CLCN5 mediating the excitatory $\mathrm{Cl}(-)$ currents activated by sphingosine-1-phosphate in sensory neurons. Front. Mol. Neurosci. 11:33. doi: 10.3389/fnmol.2018.00033

Qiu, Z., Dubin, A. E., Mathur, J., Tu, B., Reddy, K., Miraglia, L. J., et al. (2014). SWELL1, a plasma membrane protein, is an essential component of volume-regulated anion channel. Cell 157, 447-458. doi: 10.1016/j.cell.2014. 03.024

Quarta, S., Camprubi-Robles, M., Schweigreiter, R., Matusica, D., Haberberger, R. V., Proia, R. L., et al. (2017). Sphingosine-1-Phosphate and the S1P3 receptor initiate neuronal retraction via RhoA/ROCK associated with CRMP2 phosphorylation. Front. Mol. Neurosci. 10:317. doi: 10.3389/fnmol.2017.00317

Raimondo, J. V., Markram, H., and Akerman, C. J. (2012). Short-term ionic plasticity at GABAergic synapses. Front. Synaptic Neurosci. 4:5. doi: 10.3389/ fnsyn.2012.00005

Ran, R., Gu, J., Fu, J., Zhong, H., Zhao, Y., Gu, Y., et al. (2014). The role of the GABA-A receptor of the adjacent intact dorsal root ganglion neurons in rats with neuropathic pain. Acta Neurobiol. Exp. 74, 405-414.

Reznikov, L. R. (2017). Cystic fibrosis and the nervous system. Chest 151, 1147 1155. doi: 10.1016/j.chest.2016.11.009

Reznikov, L. R., Dong, Q., Chen, J. H., Moninger, T. O., Park, J. M., Zhang, Y., et al. (2013). CFTR-deficient pigs display peripheral nervous system defects at birth. Proc. Natl. Acad. Sci. U.S.A. 110, 3083-3088. doi: 10.1073/pnas.1222729110

Rivera, C., Voipio, J., Payne, J. A., Ruusuvuori, E., Lahtinen, H., Lamsa, K., et al. (1999). The $\mathrm{K}+/ \mathrm{Cl}$ - co-transporter KCC2 renders GABA hyperpolarizing during neuronal maturation. Nature 397, 251-255. doi: 10.1038/16697

Robertson, B. (1989). Characteristics of GABA-activated chloride channels in mammalian dorsal root ganglion neurones. J. Physiol. 411, 285-300. doi: 10. 1113/jphysiol.1989.sp017574

Rocha-Gonzalez, H. I., Mao, S., and Alvarez-Leefmans, F. J. (2008). Na+,K+,2Clcotransport and intracellular chloride regulation in rat primary sensory neurons: thermodynamic and kinetic aspects. J. Neurophysiol. 100, 169-184. doi: 10.1152/jn.01007.2007

Rogan, M. P., Reznikov, L. R., Pezzulo, A. A., Gansemer, N. D., Samuel, M., Prather, R. S., et al. (2010). Pigs and humans with cystic fibrosis have reduced insulinlike growth factor 1 (IGF1) levels at birth. Proc. Natl. Acad. Sci. U.S.A. 107, 20571-20575. doi: 10.1073/pnas.1015281107

Rudomin, P., and Schmidt, R. F. (1999). Presynaptic inhibition in the vertebrate spinal cord revisited. Exp. Brain Res. 129, 1-37. doi: 10.1007/s002210050933

Sabirov, R. Z., Merzlyak, P. G., Islam, M. R., Okada, T., and Okada, Y. (2016). The properties, functions, and pathophysiology of maxi-anion channels. Pflugers. Arch. 468, 405-420. doi: 10.1007/s00424-015-1774-5

Sabirov, R. Z., Merzlyak, P. G., Okada, T., Islam, M. R., Uramoto, H., Mori, T., et al. (2017). The organic anion transporter SLCO2A1 constitutes the core component of the Maxi-Cl channel. EMBO J. 36, 3309-3324. doi: 10.15252/ embj. 201796685

Sabirov, R. Z., and Okada, Y. (2005). ATP release via anion channels. Purinerg. Signal. 1, 311-328. doi: 10.1007/s11302-005-1557-0

Saji, M., and Obata, K. (1981). Stimulus-dependent labeling of cultured ganglionic cell with [14C]2-deoxyglucose. Brain Res. 212, 435-446. doi: 10.1016/00068993(81)90475-3

Sala-Rabanal, M., Yurtsever, Z., Nichols, C. G., and Brett, T. J. (2015). Secreted CLCA1 modulates TMEM16A to activate Ca2+-dependent chloride currents in human cells. eLife 4:5875. doi: 10.7554/eLife.05875

Salzer, I., Gantumur, E., Yousuf, A., and Boehm, S. (2016). Control of sensory neuron excitability by serotonin involves $5 \mathrm{HT} 2 \mathrm{C}$ receptors and $\mathrm{Ca} 2+$ activated chloride channels. Neuropharmacology 110, 277-286. doi: 10.1016/j. neuropharm.2016.08.006

Schreiber, R., Ousingsawat, J., Wanitchakool, P., Sirianant, L., Benedetto, R., Reiss, K., et al. (2018). Regulation of TMEM16A/ANO1 and TMEM16F/ANO6 ion currents and phospholipid scrambling by $\mathrm{Ca}(2+)$ and plasma membrane lipid. J. Physiol. 596, 217-229. doi: 10.1113/JP275175

Schroeder, B. C., Cheng, T., Jan, Y. N., and Jan, L. Y. (2008). Expression cloning of TMEM16A as a calcium-activated chloride channel subunit. Cell 134, 10191029. doi: 10.1016/j.cell.2008.09.003

Shypshyna, M. S., and Veselovs'kyi, M. S. (2010). Characteristics of sensory neurotransmission in co-culture of neurons from the dorsal root ganglion and dorsal horn spinal cord in rats. Fiziol. Zh. 56, 26-36. doi: 10.15407/fz56.04.026

Si, J. Q., Zhang, Z. Q., Li, C. X., Wang, L. F., Yang, Y. L., and Li, Z. W. (2004) Modulatory effect of substance P on GABA-activated currents from rat dorsal root ganglion. Acta Pharmacol. Sin. 25, 623-629.

Sigel, E., and Steinmann, M. E. (2012). Structure, function, and modulation of GABA(A) receptors. J. Biol. Chem. 287, 40224-40231. doi: 10.1074/jbc.R112. 386664

Sokolova, E., Nistri, A., and Giniatullin, R. (2001). Negative cross talk between anionic GABAA and cationic P2X ionotropic receptors of rat dorsal root ganglion neurons. J. Neurosci. 21, 4958-4968. doi: 10.1523/jneurosci.21-1404958.2001 
Steinmeyer, K., Ortland, C., and Jentsch, T. J. (1991). Primary structure and functional expression of a developmentally regulated skeletal muscle chloride channel. Nature 354, 301-304. doi: 10.1038/354301a0

Strege, P. R., Bernard, C. E., Mazzone, A., Linden, D. R., Beyder, A., Gibbons, S. J., et al. (2015). A novel exon in the human Ca2+-activated Cl- channel Ano1 imparts greater sensitivity to intracellular Ca2+. Am. J. Physiol. Gastrointest. Liver Physiol. 309, G743-G749. doi: 10.1152/ajpgi.00074.2015

Sun, H., Tsunenari, T., Yau, K.-W., and Nathans, J. (2002). The vitelliform macular dystrophy protein defines a new family of chloride channels. Proc. Natl. Acad. Sci. U.S.A. 99, 4008-4013. doi: 10.1073/pnas.052692999

Sung, K. W., Kirby, M., McDonald, M. P., Lovinger, D. M., and Delpire, E. (2000). Abnormal GABA(A) receptor-mediated currents in dorsal root ganglion neurons isolated from Na-K-2Cl cotransporter null mice. J. Neurosci. 20, 7531-7538. doi: 10.1523/jneurosci.20-20-07531.2000

Suzuki, M., and Mizuno, A. (2004). A novel human Cl-channel family related todrosophila flightlesslocus. J. Biol. Chem. 279, 22461-22468. doi: 10.1074/jbc. m313813200

Takayama, Y., Uta, D., Furue, H., and Tominaga, M. (2015). Pain-enhancing mechanism through interaction between TRPV1 and anoctamin 1 in sensory neurons. Proc. Natl. Acad. Sci. U.S.A. 112, 5213-5218. doi: 10.1073/pnas. 1421507112

Toulme, E., Blais, D., Leger, C., Landry, M., Garret, M., Seguela, P., et al. (2007). An intracellular motif of $\mathrm{P} 2 \mathrm{X}(3)$ receptors is required for functional crosstalk with GABA(A) receptors in nociceptive DRG neurons. J. Neurochem 102, 1357-1368. doi: 10.1111/j.1471-4159.2007.04640.x

Valeyev, A. Y., Hackman, J. C., Holohean, A. M., Wood, P. M., Katz, J. L., and Davidoff, R. A. (1999). GABA-Induced Cl- current in cultured embryonic human dorsal root ganglion neurons. J. Neurophysiol. 82, 1-9. doi: 10.1152/ jn.1999.82.1.1

Valeyev, A. Y., Hackman, J. C., Wood, P. M., and Davidoff, R. A. (1996). Pharmacologically novel GABA receptor in human dorsal root ganglion neurons. J. Neurophysiol. 76, 3555-3558. doi: 10.1152/jn.1996.76.5.3555

Vikman, K. S., Hill, R. H., Backstrom, E., Robertson, B., and Kristensson, K. (2003). Interferon-gamma induces characteristics of central sensitization in spinal dorsal horn neurons in vitro. Pain 106, 241-251. doi: 10.1016/s03043959(03)00262-8

Vlachova, V., Lyfenko, A., Orkand, R. K., and Vyklicky, L. (2001). The effects of capsaicin and acidity on currents generated by noxious heat in cultured neonatal rat dorsal root ganglion neurones. J. Physiol. 533(Pt 3), 717-728. doi: 10.1111/j.1469-7793.2001.t01-1-00717.x

Voss, F. K., Ullrich, F., Munch, J., Lazarow, K., Lutter, D., Mah, N., et al. (2014). Identification of LRRC8 heteromers as an essential component of the volumeregulated anion channel VRAC. Science 344, 634-638. doi: 10.1126/science. 1252826

Wang, H. C., Cheng, K. I., Chen, P. R., Tseng, K. Y., Kwan, A. L., and Chang, L. L. (2018). Glycine receptors expression in rat spinal cord and dorsal root ganglion in prostaglandin E2 intrathecal injection models. BMC Neurosci. 19:72. doi: 10.1186/s12868-018-0470-8

Wang, R., Lu, Y., Gunasekar, S., Zhang, Y., Benson, C. J., Chapleau, M. W., et al. (2017). The volume-regulated anion channel (LRRC8) in nodose neurons is sensitive to acidic pH. JCI Insight. 2:e90632. doi: 10.1172/jci.insight. 90632

Wanitchakool, P., Ousingsawat, J., Sirianant, L., Cabrita, I., Faria, D., Schreiber, R., et al. (2017). Cellular defects by deletion of ANO10 are due to deregulated local calcium signaling. Cell. Signal. 30, 41-49. doi: 10.1016/j.cellsig.2016.11.006

White, G. (1990). GABAA-receptor-activated current in dorsal root ganglion neurons freshly isolated from adult rats. J. Neurophysiol. 64, 57-63. doi: 10. 1152/jn.1990.64.1.57

Witschi, R., Punnakkal, P., Paul, J., Walczak, J. S., Cervero, F., Fritschy, J. M., et al. (2011). Presynaptic alpha2-GABAA receptors in primary afferent depolarization and spinal pain control. J. Neurosci. 31, 8134-8142. doi: 10.1523/ JNEUROSCI.6328-10.2011
Wright, R., Raimondo, J. V., and Akerman, C. J. (2011). Spatial and temporal dynamics in the ionic driving force for GABA A receptors. Neural Plast. 2011:728395. doi: 10.1155/2011/728395

Wu, X. P., Li, Z. W., and Fan, Y. Z. (1994). Inhibitory effect of SP on GABAactivated currents in freshly isolated rat DRG neurons. Sheng Li Xue Bao 46, 586-590.

Xi, Z. X., and Akasu, T. (1996). N-methyl-D-aspartate depresses GABAA receptormediated currents in neurons of bullfrog dorsal root ganglia. Neurosci. Lett. 212, 17-20. doi: 10.1016/0304-3940(96)12771-3

Xiong, W., Cui, T., Cheng, K., Yang, F., Chen, S. R., Willenbring, D., et al. (2012). Cannabinoids suppress inflammatory and neuropathic pain by targeting alpha3 glycine receptors. J. Exp. Med. 209, 1121-1134. doi: 10.1084/jem.20120242

Yamada, K., and Akasu, T. (1996). Substance P suppresses GABAA receptor function via protein kinase $\mathrm{C}$ in primary sensory neurones of bullfrogs. J. Physiol. 496(Pt 2), 439-449. doi: 10.1113/jphysiol.1996.sp021697

Yang, T., Liu, Q., Kloss, B., Bruni, R., Kalathur, R. C., Guo, Y., et al. (2014). Structure and selectivity in bestrophin ion channels. Science 346, 355-359. doi: 10.1126/science. 1259723

Yang, Y. D., Cho, H., Koo, J. Y., Tak, M. H., Cho-Shim, Y. W., Park, S., et al. (2008). TMEM16A confers receptor-activated calcium-dependent chloride conductance. Nature 455, 1210-1215. doi: 10.1038/nature07313

Yang, Y. L., Yao, K. H., Gu, Y. Z., Guan, B. C., and Li, Z. W. (2003). Three kinds of current in response to substance P in bullfrog DRG neurons. Brain Res. 981, 70-77. doi: 10.1016/s0006-8993(03)02949-4

Ye, W., Han, T. W., He, M., Jan, Y. N., and Jan, L. Y. (2019). Dynamic change of electrostatic field in TMEM16F permeation pathway shifts its ion selectivity. eLife 8:e45187. doi: 10.7554/eLife.45187

Zeilhofer, H. U., Mohler, H., and Di Lio, A. (2009). GABAergic analgesia: new insights from mutant mice and subtype-selective agonists. Trends Pharmacol. Sci. 30, 397-402. doi: 10.1016/j.tips.2009.05.007

Zhang, M., Gao, C. X., Wang, Y. P., Ma, K. T., Li, L., Yin, J. W., et al. (2018). The association between the expression of PAR2 and TMEM16A and neuropathic pain. Mol. Med. Rep. 17, 3744-3750. doi: 10.3892/mmr.2017.8295

Zhang, Y., Chen, K., Sloan, S. A., Bennett, M. L., Scholze, A. R., O’Keeffe, S., et al. (2014). An RNA-sequencing transcriptome and splicing database of glia, neurons, and vascular cells of the cerebral cortex. J. Neurosci. 34, 11929-11947. doi: 10.1523/JNEUROSCI.1860-14.2014

Zhang, Y., Zhao, S., Rodriguez, E., Takatoh, J., Han, B. X., Zhou, X., et al. (2015). Identifying local and descending inputs for primary sensory neurons. J. Clin. Invest. 125, 3782-3794. doi: 10.1172/JCI81156

Zhang, Y. H., Fehrenbacher, J. C., Vasko, M. R., and Nicol, G. D. (2006). Sphingosine-1-phosphate via activation of a G-protein-coupled receptor(s) enhances the excitability of rat sensory neurons. J. Neurophysiol. 96, 1042-1052. doi: $10.1152 /$ jn. 00120.2006

Zhu, Y., Lu, S. G., and Gold, M. S. (2012). Persistent inflammation increases GABAinduced depolarization of rat cutaneous dorsal root ganglion neurons in vitro. Neuroscience 220, 330-340. doi: 10.1016/j.neuroscience.2012.06.025

Zimmerman, A. L., Kovatsis, E. M., Pozsgai, R. Y., Tasnim, A., Zhang, Q., and Ginty, D. D. (2019). Distinct modes of presynaptic inhibition of cutaneous afferents and their functions in behavior. Neuron 102, 420-434.e8. doi: 10.1016/ j.neuron.2019.02.002

Conflict of Interest: The authors declare that the research was conducted in the absence of any commercial or financial relationships that could be construed as a potential conflict of interest.

Copyright (c) 2020 Wilke, Kummer, Leitner and Kress. This is an open-access article distributed under the terms of the Creative Commons Attribution License (CC BY). The use, distribution or reproduction in other forums is permitted, provided the original author(s) and the copyright owner(s) are credited and that the original publication in this journal is cited, in accordance with accepted academic practice. No use, distribution or reproduction is permitted which does not comply with these terms. 